\title{
Prawo właściwe dla skutków przelewu wierzytelności w stosunku do osób trzecich Uwagi z perspektywy międzynarodowego prawa upadłościowego
}

\begin{abstract}
Abstract: The claims are rights in personam but the assignment of claims has a hybrid nature. Abolishing the "nomina ossibus inhaerent" rule has increased commercial significance of the assignment of claims. However, the contemporary legal situation leaves parties with great legal uncertainty, as to the question under which circumstances does the cross - borders assignment is valid. A recent judgment of the CJEU of 9 October 2019 (C - 548/18) in case BGL BNP Paribas SA v. TeamBank AG Nürnberg has augmented this uncertainty. The Luxemburg Court ruled that: "Article 14 of the Regulation (EC) No 593/2008 of the European Parliament and of the Council of 17 June 2008 ('Rome I') must be interpreted as not designating, directly or by analogy, the applicable law concerning the third-party effects of the assignment of a claim in the event of multiple assignments of the claim by the same creditor to successive assignees". In this situation, one would highly welcome an attempt to establish a new set of conflict of laws rules relating to the law applicable to third - parties effects of the assignment of claims. This attempt has recently been made by the European Commission in its Report "on the question of the effectiveness of an assignment or subrogation of a claim against third parties and the priority of the assigned or subrogated claim over the right of another person", dated 29 September 2016. In the present article, the author reviews the most important propositions formulated in the conflicts' doctrine through the "lens" of the international insolvency law. Multiply provisions of the Regulation (EU) 2015/848 of 20 May 2015 on insolvency proceedings (recast) - despite many judgments of the CJEU in this area also lack certainty. Insolvency is a foreseeable risk, but without clear rules concerning
\end{abstract}

a) Dr hab., prof. UŚ, Uniwersytet Śląski w Katowicach. 
the third parties' effects of the assignment of claims, it may become unenforceable for the creditors of the assignor.

Keywords: assignment, Rome Regulation, Insolvency Regulation, property, center of main interest of the debtor, rights in rem, detrimental acts, location of the claim

\section{Uwagi wstępne}

Współcześnie przedmiotem intensywnego zainteresowania wśród przedstawicieli doktryny jest zagadnienie prawa właściwego dla rzeczowych skutków przelewu wierzytelności ${ }^{1}$. Problem ten nurtuje również judykaturę 2 . I tak: wśród wypowiedzi ponadnarodowych organów judykacyjnych $^{3}$ zwraca uwage pochodząca z 9 października 2019 r. (C - 548/18) wypowiedź TSUE, w sprawie BGL BNP Paribas SA/ Tea-

${ }^{1}$ G. Cuniberti: La proposition de règlement de la Commission sur la loi applicable à l'opposabilitè des cessions de créances. „Revue critique de droit international privè” [dalej Rev. crit. dr. int. pr.] 2018, z. 4 , s. 793-799; H. Labontè: Third-Party effects of the assigments of claims: new momentum from Commision's Capital Markets Union Action Plan an the Commision's 2018 Proposal. „Journal of Private International Law” [dalej JPIL] 2018, vol. 14, n 2, s. 319-342; M.F. Müller: Drittwirkungen der Forderungsübetragung „zum Dritten”. „Europäische Zeitschrift für Wirtschaftsrecht” [dalej EuZW] 2018, s. 522 i n; C. Wals h: The Role of Party Automy in Determing the ThirdParty Effects of Assignments: of "Secret Laws” and "Secret Liens”. , Law \& Contemporary Problems", 2018, t. 81, nr 1, s. 181-202; C.A. de Vis ser: The EU conflict of laws rules on the law governing the effects of an assignment against third parties: some fundamental problems of Proposal. "Nederlands Internationaal Privaatrecht” [dalej NIPR] 2018, z. 4, s. 711-724; S.V. Bazinas: The law applicable to third -party effects of assignments of claims: the UN Convention and the EU Commissions Proposal compared. „Uniform Law Review” [dalej Unif. Law Rev.] 2019, vol. 0, s. 1-24; E.M. Kieninger: Das auf die Drittwirkungen der Abtretung anwendbares Recht Die EugH spielt die Balle zurück nach Deutschland. „Neue Juristische Wochenschrift” [dalej NJW] 2019, z. 46, s. 3353-3356; H. Kronke: Assignment of Claims and Proprietary Effects: Overview of Doctrinal Debate and the EU Commission's Proposal. Oslo Law Review, vol. 6, 1- 2019, s. 8-18.

${ }^{2}$ Zdaniem E.M. Kieninger, to wypowiedź holenderskiego SN z (Hoge Raad) z 16.05.1997 r. IPRax 1999, s. 280) wywołała lawinę wypowiedzi w doktrynie, taż: Das auf die Drittwirkungen..., s. 3354.

${ }^{3}$ Zauważyć należy, iż wskazane przed laty prze K. Siehra postulaty odnoszące się do formułowania rozstrzygnięć mogących mieć „precedensowe” znaczenie w tych obszarach prawa kolizyjnego, które stanowią lacunae legis nie zostały współcześnie zrealizowane, tenże: Vom Lesen und Schreiben Kollisionsrechtlicher Entscheidungen. „Rabels Zeitschrift für ausländisches und internationals Privatrecht” [dalej RabelsZ] 1974, t. 38, z. $2-3$, s. $631-634$. 
mBank AG Nürnberg ${ }^{4}$. Organ ten - odpowiadajac na rozbudowane pytania wstępne - zadane mu w dniu 8 sierpnia 2018 r. (4 U 109/17) ${ }^{5}$ przez Wyższy Sąd Krajowy (Oberlandesgericht) w Saarbrücken - nawiązał do „genetycznej” wykładni ${ }^{6}$ postanowień rozp. Rzym I7. Sędziowie w Luksemburgu stwierdzili - w nawiązaniu do dominującego współcześnie $\mathrm{w}$ piśmiennictwie zapatrywania ${ }^{8}$ - iż ,przepis art. 14 rozp. Rzym I należy interpretować $\mathrm{w}$ ten sposób, że nie wskazuje on - ani bezpośrednio, ani poprzez analogię - prawa właściwego dla kwestii skuteczności wobec osób trzecich przelewu wierzytelności w przypadku wielokrotnego przelewu wierzytelności dokonywanego przez tego samego wierzyciela na rzecz kolejnych cesjonariuszy". Natomiast do łacznika siedziby cedenta

${ }^{4}$ P. Mankowski: Komentarz (Anmerkung) do orzeczenia TSUE z 9 października 2018 r. (C - 548/18). „Recht der internationalen Wirtschaft” [dalej RIW] 2019, z. 11, s. 728-729; C. Schmitt: komentarz do orzeczenia TSUE z 9 października 2019 r. EuZW 2019, s. 939.

${ }^{5}$ „Entscheidungen zum Wirtschaftsrecht” [dalej EWiR] 2018, z. 23, s. 735 wraz z komentarzem P. Mankowskiego; zauważyć należy, iż pytanie wstępne jest niezwykle rozbudowane, gdyż liczy sobie 15 stron maszynopisu. I tak: na wstępie Sąd „odsyłajacy” rozważył kwestię, czy w art. 14 rozp. Rzym I unormowano kwestię prawa właściwego dla „rzeczowych skutków” przelewu (s. 8-10), w dalszej kolejności — zagadnienie przedłożone TSUE - dzieli się na mniejsze fragmenty określające poszczególne warianty na wypadek pozytywnej lub negatywnej odpowiedzi TSUE; na marginesie zauważyć należy, iż sąd niemiecki rozważał także zagadnienie analogicznego stosowania rozp. Rzym I; niestety polski przekład pytania — opubl. w DzU. Unii C 436, z 3 grudnia 2018 r. https:// eur-lex.europa.eu/legal-content/PL/TXT/PDF/?uri=OJ:C:2018:436:FULL\&from=PL (dostęp z 13 stycznia 2020 r.) - nie odzwierciedla bogactwa stanowisk przedstawionych w pytaniu wstępnym zadanym przez Wyższy Sąd Krajowy w Saarbrücken.

${ }^{6}$ Słabości tego typu zabiegów interpretacyjnych dostrzegł przed laty T.H.D. Struycken, który zauważył, odnośnie do konw. rzymskiej o prawie właściwym dla zobowiąań umownych z 9 czerwca 1980 r., iż: analiza travaux préparatoires towarzyszacych konwencji rzymskiej prowadzi do podwójnego ,zaskoczenia”, gdyż materie, które sq istotne, zostaty pominięte, natomiast określenia znajdujace się $w$ tych dokumentach nie oddaja tego, co $w$ istocie znacza lub nie maja znaczenia „The analysis of the travaux préparatoires of the Rome Convention has a peculiar twist to it: what in not in official Report is significant, but what is there either nor means what it seems to say or carries no weight", Idem: The Proprietary Aspects of International Assignments of Debts and Rome Convention, Art 12, Lloyd's Maritime and Commercial Law Quaterly [dalej LMCLQ] 1998, z. 6, s. 350.

${ }^{7}$ Dz.U. Unii z 4.07.2008 r., l. 177/6 z późn. zmian.

${ }^{8}$ P. Lagarde, A. Tenenbaum: De la convention de Rome au reglement Rome I. Rev. crit. dr. int. pr. 2008, z. 4, s. 776-777; H.J. Sonnenberger: Randbemerkungen zum Allgemeinen Teil eines europäisierten IPR. w: Die richtige Ordnung Festschrift für Jan Kropholler zum 70 Geburtstag, Tübingen 2008, s. 230-232; D. Martiny, w: Münchener Kommentar zum BGB, ART 14 Rom - I VO. 7. Auflage, München 2018, nb. 19; H.P. Mansell, K. Thorn, R. Wagner: Europäisches Kollisionsrecht 2018: Endspurt!. „Praxis des internationalen Privat- und Verfahrensrecht” [dalej IPRax 2019], z. 2, s. $85-119$. 
nawiązuje wypowiedź norweskiego SN (Højesterett) z 28 czerwca 2017 r. (HR - 2017-1297-A) w sprawie Bergen Bunkers 9 .

Zauważyć należy, że wypowiedzi przedstawicieli doktryny i organów orzekających uwzględniane są w trakcie starań - wpisujących się w idee „denacjonalizacji” prawa prywatnego międzynarodowego ${ }^{10}$ podejmowanych zarówno przez Unię, jak i Komisję do spraw Unifikacji Międzynarodowego Prawa Handlowego (United Nations Commission on International Trade Law, UNCITRAL) ${ }^{11}$, działajaca przy Organizacji Narodów Zjednoczonych ${ }^{12}$. I tak, wskazać tu należy na sprawozdanie Komisji sporządzone dla Parlamentu Europejskiego, Rady i Europejskiego Komitetu Ekonomiczno - Społecznego ${ }^{13}$ z 26 września 2016 r. $^{14}$ stanowiace podłoże dla projektu — pochodzącego z 12 marca 2018 r. — rozporządzenia w sprawie prawa właściwego dla skutków przelewu wierzytelności wobec osób trzecich (rozp. w spraw. praw. właściw. dla skutk. przelew. wobec os. trzec. $)^{15}$. Interesujące jest to, iż pkt 23 preambuły do wskazanego projektu nawiązuje - do opracowanej niemalże dwie dekady temu przez

${ }^{9}$ K. Lillehot: Norwegian Supreme Court: The Law of the Assignor's Home Country is Applicable to Third - Parties Effects of Assigments of Claims. IPRax 2018, z. 5, s. $539-541$.

${ }^{10}$ D.P. Fernández Arroyo: Denationalising Private International Law - A Law with Multiple Adjudicators and Enforces. Yearbook of Private International Law, vol. XX 2018/2019, s. 31-45.

${ }^{11}$ Ten organ powołało w dniu 17 grudnia 1966 r. Zgromadzenie Ogólne Narodów Zjednoczonych, zobacz B. Frigge: Externe Lücken und internationales Privatrecht im UN - Kaufrecht (Art 7 Abs. 2), Frankfurt am Main 1994, s. 27-28.

${ }^{12} \mathrm{Na}$ uwagę zasługuje również apel, opracowany podczas czterdziestej czwartej sesji UCITRAL, która odbyła się na przełomie lipca i sierpnia 2011 r. To gremium poddało pod rozwagę organom Unii, to aby w trakcie prac nad przyszła regulacją w zakresie prawa właściwego dla rzeczowych skutków przelewu uwzględnić konwencję nowojorska o przelewie wierzytelności w handlu międzynarodowym; https://undocs.org/en/A/66/17, (dostęp z 11 grudnia 2019).

${ }^{13}$ Fundamentem dla wskazanego sprawozdania był - pochodzacy z połowy grudnia 2011 r. - raport Brytyjskiego Instytutu Prawa Międzynarodowego i Porównawczego (British Institute of International and Comparative Law) sporządzony przez zespół kierowany przez E. Lein oraz A. Dickinsona; Istota tego obszernego dokumentu jest jego część czwarta (określona na s. 148-372) poprzedzająca końcowy jego fragment zatytułowany „Rozwój Reguł Odnoszących się do Przelewu w rozp. Rzym I” (s. 373-415); E.M. Kieniger: Die auf die Forderungsabtretung anzuwendende Recht im Licht der BIICL - Studie. IPRax 2012, z. 4, s. 289-297.

${ }^{14}$ COM 2016 (626) final.

${ }^{15}$ G. Cuniberti: La proposition..., s. 793 - 799; zobacz równiė̇ sprawozdanie w sprawie wniosku dotyczącego rozporządzenia Parlamentu Europejskiego i Rady w sprawie prawa właściwego dla skutków przelewu wierzytelności wobec osób trzecich (COM(2018)0096 - C8-0109/2018 - 2018/0044(COD)), z 16 lipca 2019 r. jak również Rezolucję ustawodawcza Parlamentu Europejskiego z dnia 13 lutego 2019 r. w sprawie wniosku dotyczącego rozporządzenia Parlamentu Europejskiego i Rady w sprawie prawa 
Komisję do spraw Międzynarodowego Prawa Handlowego (UNCITRAL) - Konwencji nowojorskiej o przelewie wierzytelności w handlu międzynarodowym (tzw. konw. nowojor. o cesji) ${ }^{16}$. Akt ten - przyjęty w dniu 12 grudnia $2001 \mathrm{r}$. — został podpisany jedynie przez trzy państwa: Luksemburg, Madagaskar oraz Stany Zjednoczone Ameryki ${ }^{17}$. Jednakże współcześnie rozpoczyna się nowa „epoka” w historii tych unormowań, gdyż konw. nowojor. o cesji została ratyfikowana - w dniu 15 października 2019 r. $^{18}$ - przez Stany Zjednoczone Ameryki ${ }^{19}$. W konsekwencji akt ten doczekał się już drugiej ratyfikacji ${ }^{20}$. Natomiast w myśl art. 45 ust. 1 konw. nowojor. o cesji do wejścia w życie tej umowy międzynarodowej wymagane sa trzy kolejne ratyfikacje. Obydwa projekty nawiazuja do myśli wyrażonej przez J. Krophollera, który stwierdził, że wyzwania, które przynosi rozwój prawa prywatnego międzynarodowego wymagaja „nowoczesnych” rozwiązań ${ }^{21}$.

Zauważyć należy, iż de lege lata uczestnicy międzynarodowych transakcji finansowych napotykaja na daleko posunięta niepewność prawa wiążącą się z możliwością powstania „zjawiska” forum shopping ${ }^{22}$. Po-

właściwego dla skutków przelewu wierzytelności wobec osób trzecich (COM(2018)0096 - C8-0109/2018 - 2018/0044(COD)).

${ }^{16}$ W. Kurowski: Przelew wierzytelności w handlu międzynarodowym. „Kwartalnik Prawa Prywatnego" [dalej KPP] R: XIII: 2004, z. 4, s. 1133-1193; W. Kurowski, w: W. Popiołek, (red.), System Prawa Handlowego, Tom 9 Międzynarodowe Prawo Handlowe. Warszawa 2013, s. 773-776.

${ }^{17} \mathrm{https} / / /$ uncitral.un.org/en/texts/securityinterests/conventions/receivables/status, (dostęp z 13 grudnia 2019 r.)

18 https:/uncitral.un.org/en/texts/securityinterests/conventions/receivables/status, (dostęp z 26 listopada 2019 r.).

${ }_{19}$ S.V. Bazinas: The law applicable..., s. 1-24.

${ }^{20}$ Pierwszym państwem, które ratyfikowało w dniu 16.09.2005 r., konw. nowojor. o cesji była Liberia, https://uncitral.un.org/en/texts/securityinterests/conventions/receivables/status, dostęp z 4 stycznia $2020 \mathrm{r}$.

${ }^{21}$ J. Kropholler: Der „Auschluss“ des Internationales Privatrechts im Einheitlichen Kaufgesetz. RabelsZ 1974, t. 28, z. 2-3, s. 372-387.

${ }^{22}$ F. Ferrari, w: J. Basedow, G. Rühl, F. Ferrari, P. de Miguel Asensio (ed.) Encyclopedia - of- Private International Law vol. 1, Entries A-H, s. 789-797; C. Cavicchioli: Forum Shopping in International Litigation. „Yearbook of Private International Law” vol. XX 2018/2019, s. 413-438; zobacz również wypowiedź sądu amerykańskiego (United States District Court, W.D. Pensylwania) z 13 marca 2006 r. (No. 2:06CV48.) w sprawie F.R. Zokaites v. Land - Cellular Corporation and R. Moses, 424 Fed. Supp.2d 824, przy czym szczególnie interesujące są tezy 19-21 - towarzyszącego temu rozstrzygnięciu - uzasadnienia; odnośnie do wypowiedzi doktryny poświęconych prawu właściwemu dla rzeczowych skutków przelewu - w kontekście forum shopping — zobacz np: R. Fentiman: Trading Debts across the Borders: A European Solution. Indiana Journal of Global Legal Studies, 2010, z. 2, s. 245-272; Y. Nishitani: Cross - border assignment of receivables: conflict of laws in secured transactions. Unif. Law Rev. 
nadto cesjonariusz, aby upewnić się, czy rzeczywiście przysługuje mu stanowiąca przedmiot przelewu wierzytelność, musi, w świetle orzeczenia TSUE z 9 października 2019 r. (C-548/18) uwzględnić ex ante wszystkie przesłanki skuteczności przelewu ${ }^{23}$ określone w wielu systemach prawnych ${ }^{24}$. I tak, w grę wejdzie, obok systemu prawnego stanowiącego statut wierzytelności, również prawo wskazane przez normy kolizyjne obowiązujące w prawie państwa, w którym znajduje się — podstawowy dla międzynarodowego prawa upadłościowego (międz. pr. upadł) ${ }^{25}$ — łącznik, wskazujący prawo właściwe dla materialnych i procesowych skutków wiążących się z ogłoszeniem upadłości w postaci „głównego ośrodka podstawowej działalności dłużnika"26. Nie bez znaczenia są unormowania prawa prywatnego międzynarodowego obowiązujące w siedzibie dłużnika wierzytelności, stanowiącej przedmiot przelewu. Wreszcie w przypadku przelewów na zabezpieczenie lub innych praw zabezpieczajacych majacych za przedmiot wierzytelność należy brać pod uwagę art. 8 ust. 1 oraz art. 8 ust. 2 lit. „b” r.m.p.u. 2015/848 ${ }^{27}$. Potencjalnie moga wejść w grę niezwykle złożone regulacje pozwalajace na wyznaczenia prawa właściwego dla zaskarżenia czynności dokonanych przez upadłego cedenta określone w art. 16 r. m. p. u 2015/848 28 .

W związku z tym, iż zagadnienia powstające na styku prawa właściwego dla skutków przelewu względem osób trzecich i międz. pr. upadł. nie były — jak się wydaje — przedmiotem szerszej debaty w piśmien-

2017, vol. 22, s. 826-841; M.F. Müller: Drittwirkungen der Forderungsübetragung..., s. 522 i n.

${ }^{23}$ Odnośnie do tendencji występujacych w poszczególnych systemach prawnych w tym zakresie zob. np: A. Morell, F. Helsen: The Interrelation of Tansparency and Availability of Collateral: German and Belgian Laws of Non - possessory Security Interests. „European Review of Private Law”, 2014, z. 3, s. 393 [dalej Eur. Rev. Priv. Law]; C. Walsh: The Role of Party autonomy..., s. 185-189.

${ }^{24}$ R. Freitag: Der Statut der Drittwirkungen einer Abtretung. „Zivilrecht — LMK“ 2019, nr 424074 .

${ }^{25}$ Odnośnie do pojęcia, stanu i perspektyw rozwoju tej części prawa prywatnego międzynarodowego sensu largo, zob. W. Klyta: Uznanie zagranicznych postępowań upadtościowych. Warszawa 2008, s. 19-24.

${ }^{26}$ Zob. art. 3 Rozporządzenia Parlamentu Europejskiego i Rady z 20 maja 2015 r. o postępowaniu upadłościowym (wersja przekształcona), Dz. UE L 141/19 z 5 czerwca 2015 r. (r.m.p.u. 2015/848.); zauważyć należy, że postanowienia przejściowe i końcowe zostały unormowane w rozdziale VII tego aktu. W myśl - rozpoczynającego ten rozdział - bardzo niestarannie zredagowanego, art. 84 rozp. 2015/848, wskazany akt stosuje się do postępowań upadłościowych, objętych jego zakresem, wszczętych w dniu 26 czerwca 2017 r. oraz wszystkich tego typu procedur ogłoszonych po upływie owego terminu w przyszłości.

${ }^{27}$ C. Heinze, C.J. Warmuth: The law applicable to proprietary effects of assignment and its interplay with insolvency. Unif. Law Rev. 2017, vol. 22, s. 808-825.

${ }^{28}$ C. Heinze, C.J. Warmuth: The law applicable..., s. 808-825. 
nictwie $^{29}$, wydaje się uzasadnione poświęcenie tym zagadnieniom kilku szkicowych uwag.

\section{Pojęcie „rzeczowych" skutków przelewu}

Współcześnie A. Dickinson - w nawiązaniu do stwierdzenia, iż omnis definitio periculosa est - zauważył, że walory pojęcia „rzeczowe skutki przelewu” czy też skutki przelewu względem osób trzecich rozumiane jako wykraczające poza skutki inter partes rozporzadzajace konsekwencje przelewu ${ }^{30}$ podczas dokonywania zabiegów kwalifikacyjnych są znikome ${ }^{31}$. Natomiast D. Einsele zauważa, iż w pierwszej kolejności w tym kontekście należy wskazać na dłużnika przenoszonej wierzytelności ${ }^{32}$. Jednakże obecnie panuje zgoda odnośnie do tego, że prawo państwa, któremu podlega przenoszona wierzytelność, rozstrzyga o jego ochronie $^{33}$. W konsekwencji „skuteczność” przelewu jest powszechnie

${ }^{29}$ Zauważyć należy, iż przed laty R. Goode stwierdził, iż związki pomiędzy rozp. Rzym I oraz unormowaniami określonymi w r.m.p.u. (zarówno w poprzedniej wersji, jak i obecnie obowiązującej wersji przekształconej) nie są wolne od licznych watpliwości, tenże: Assingment of Pure Intangibles in the Conflict of Laws, w: R. Goode, The Development of Transnational Commercial Law Policies and Problems. Oxford 2018, s. 244; współczesna wypowiedź TSUE z 8.06.2017 r. (C-54/16) w sprawie w sprawie Vinyls Italia $S p A$, w upadłości, przeciwko Mediterranea di Navigazione $S p A$ - jedynie w części przyczyniła się do wyjaśnienia tych kontrowersji; C. Thole: Die Einrede des Anfechtungsgegners gemäß Art. 16 EuInsVO 2017 (Art. 13 EuInsVO 2002) zwischen lex causae und lex fori concursus. IPRax 2018, z. 4, s. 388-392; odnośnie do konstrukcji przyjętej przez TSUE, w myśl której r.m.p.u. stanowi lex specialis w stosunku do rozp. Rzym I zgłosił - nie pozbawione racji — uwagi krytyczne P. Mankowski, tenże: Anwendbarkeit des Art. 13 EuInsVO zur Lex fori concursus - benachteiligenden Handlungen. „Neue Zeitschrift für Insolvenz - und Sanierungsrecht" [dalej NZI] 2017, z. 15-16, s. 633.

${ }^{30}$ D. Martiny, w: Münchener..., nb. 36.

${ }^{31}$ A. Dickinson: Tough Assigments: the European Commision's Proposal on the Law Applicable to the Third Party Effects of Assigments of Claims. IPRax 2018, z. 4, s. 341.

${ }^{32}$ D. Einsele: Die Drittwirkungen von Forderungsübertragung im Kollisionsrecht - ein Kritischer Zwischenruf zum Verordnungsvorschlag der Kommision. IPRax 2019, z. 6 , s. 477-483.

${ }^{33}$ Zauważyć należy, iż powyższą ideę odzwierciedla - stanowiący odzwierciedlenie zasady słuszności, do której nawiązuje przyjmowana w prawie materialnym reguła, że przelew nie może wpłynąć na stanowisko prawne dłużnika - art. 14 ust. 2 rozp. Rzym I; zob. bliżej C. von Bar: Abtretung und Legalzession im neuen deustchen IPR. RabelsZ, t. 53, z. 3, 1989, s. 468 . 
rozumiana w kontekście jego skutków „rzeczowych” ${ }^{34}$. Takie ujęcie jest konsekwencją jego hybrydalnej natury ${ }^{35}$. Może być ona zatem rozważana w stosunku pomiędzy cesjonariuszem a innymi „pretendentami” do wierzytelności, pomiędzy jej nabywcą a wierzycielami cedenta reprezentowanymi przez syndyka masy upadłości, czy też osobami trzecimi. Powyższa Autorka wyraziła interesująca myśl, iż „przenoszenie” zasady jawności praw rzeczowych na obszar prawa zobowiązań wydaje się dyskusyjne. W konsekwencji chodzi tu jedynie o ochronę interesów gospodarczych osób trzecich ${ }^{36}$. Ponadto uważa ona również, że rozważanie zagadnienia ochrony osób trzecich jest, w kontekście przelewu, w wielu aspektach dyskusyjne ${ }^{37}$. Przy czym ochrona ta winna odbywać się na płaszczyźnie prawa materialnego, które może przewidywać obowiązki wpisu do rejestru (Absolute Publizitätsmittell) albo inne rozwiązania zapewniajace skuteczność względem określonych osób, takie jak zawiadomienie o przelewie (Relative Publizitätsmittell) ${ }^{38}$. Przykładami absolutnych środków publikacyjnych sa unormowania art. 9 jednolitego kodeksu handlowego (uniform commercial code) obowiąującego w Stanach Zjednoczonych ${ }^{39}$, regulacje przewidziane przez kodeks cywilny Quebecu ${ }^{40}$, czy też unormowania obowiązujące w kanadyjskiej prowincji Saskatchewan.

Bez watpienia regulacje $\mathrm{z}$ zakresu prawa materialnego wymagają obszernego, odrębnego opracowania. W tym miejscu wskazać należy jedynie na reformę prawa zobowiązań - dokonaną na mocy rozporzadzenia z 10 lutego 2016 r. - przez prawodawcę francuskiego ${ }^{41}$. Ustawodawca francuski stworzył w nawiązaniu do postulatów przedstawicieli gospodarki, opracowań naukowych oraz osiąnnięć judykatywy całkowicie nową konstrukcję przelewu. Współczesna regulacja przybrała swą postać normatywną w art. 1321 do 1325 franc. $\mathrm{kc}^{42}$. Interesujace jest to,

${ }^{34}$ A. Flessner: Privatautonomie und Interessen im internationalen Privatrecht am Beispiel der Forderungsabtretung. w: Festschrift für Claus Wilhelm Canaris zum 70. Geburtstag, Band II, München 2007, s. 543-569; natomiast w literaturze polskiej na możliwość dokonania przelewu o skutkach czysto rozporządzających zwraca uwagę M. Pazdan: Przelew wierzytelności na zabezpieczenie. KPP, R XI:2002, z. 1, s. 124-125.

${ }^{35}$ F. Bauer: Die Forderungsabtretung im IPR. Frankfurt am Main 2008, s. 33.

${ }^{36}$ D. Einsele: Die Drittwirkungen..., s. 478-479.

${ }^{37}$ D. Einsele: Die Drittwirkungen..., s. 478-479.

${ }^{38}$ D. Einsele: Die Drittwirkungen..., s. 478-479.

${ }^{39}$ U.C.C. $\S 9-310,9-322$ (2013).

${ }^{40}$ Zob. art. 2663, art. 2945, 2950 kc obow. w Québecu C.Q.L.R., c 64.

${ }^{41}$ Ordonance Portant réforme du droit des contrats, du régime général et la preuve des obligations, JOFR Nr 0035 z 11.02.2016 r., www.legisfrance.gouv.fr. (dostęp z 1 stycznia 2020).

${ }^{42}$ Zobacz postanowienia sekcji 1 rozdziału drugiego zatytułowanego Czynności dotyczace wierzytelności, znajdującego się w Tytule czwartym zatytułowanym Ogólna regulacja zobowiązań umownych francuskiego kc. 
że ujmowany $\mathrm{w}$ dawniejszej doktrynie ${ }^{43}$ i orzecznictwie ${ }^{44}$ - jako przesłanka ważności przelewu - wymóg powiadomienia (signification) dłużnika, przewidziany przez art. 1690 (wymagającego doręczenia zawiadomienia o przelewie dłużnikowi przez komornika lub zgody dłużnika na przelew $^{45}$ - acceptation dans un actee authentique) franc. kc, należy do przeszłości ${ }^{46}$. Jak zauważył H.J. Sonnenberger, zarówno w stosunku pomiędzy cedentem a cesjonariuszem, jak i w stosunku do osób trzecich wierzytelność zostaje przeniesiona z chwila zawarcia umowy cesji ${ }^{47}$. $\mathrm{Na}$ marginesie zauważyć należy, iż wykładnia art. 1690 lukemburskiego $\mathrm{kc}^{48}$ - wzorowanego na uchylonych francuskich regulacjach — stanowiła jeden z impulsów ze strony Wyższego Sądu Krajowego w Saarbrücken do zwrócenia się w dniu 8 sierpnia 2018 r. (4 U 109/17) do TSUE z pytaniem prejudycjalnym ${ }^{49}$.

${ }^{43}$ K. Thorn: Ausländisches Akkreditiv und inländische Zahlstelle. IPRax 1996, z. 4 , s. $257-260$.

${ }^{44}$ Orzeczenie Wyższego Sądu Krajowego (Oberlandesgericht) w Köln z 25.05.1994 r. (2 U 143/93), IPRax 1996, z. 4, s. 270.

${ }^{45}$ B. Audit, L. d'Avout: Droit international privé. Issy - les - Moullineaux 2018, s. 815; w konsekwencji dokonania w zakresie poszukiwania „prawa właściwego” dla tego typu aktów osiągnięte przez przedstawicieli doktryny należą - w dużej mierze - do historii prawa międzynarodowego prywatnego.

${ }^{46}$ H.J. Sonnenberger: Die Reform des französischen Schuldvertragsrechts (Teil 2). „Zeitschrift für Europäisches Privatrecht” [dalej ZEuP] 2017, z. 4, s. 795—798.

${ }^{47}$ H.J. Sonnenberger: Die Reform..., s. 795-798.

${ }^{48}$ Zobacz znajdujące się $\mathrm{w}$ tytule VI luksemburskiego kc postanowienia rozdziału VIII zatytułowanego Du transport des créances et autres droits incorporels; szczególne znaczenie w tym zakresie odgrywa art. 1690 luksemburskiego kc; egilux.public.lu/eli/ etat/leg/code/civil/20190428, dostęp z 20 listopada 2019 r.; zobacz także F. Reinhart: Fronting für eine Captive Insurance Company. Karlsruhe 1999, s. 269, który wskazuje na różnice pomiędzy dawnym prawem francuskim a prawem Luksemburga.

${ }^{49}$ Orzeczenie zapadło na tle złożonego stanu faktycznego. I tak, przyszła dłużniczka będąca obywatelką Luksemburga, a mająca swój domicyl w Niemczech (następnie uczestniczka postępowania upadłościowego prowadzonego w stosunku osób fizycznych) zawarła w dniu 29 marca 2011 r. - podlegajacca prawu niemieckiemu - umowę kredytu z bankiem niemieckim. Osobistym zabezpieczeniem kredytu był przelew na zabezpieczenie - podlegających egzekucji - należności przysługujących jej w stosunku do pracodawcy. Następnie po upływie kilku miesięcy nawiązała nową umowę kredytu, tym razem z bankiem w Luksemburgu (nastąpiło to w dniu 15 czerwca 2011 r.), ponownie dokonujac cesji wierzytelności przysługujących jej z tytułu umowy o pracę. W dniu 5 lutego 2014 r. ogłoszono w stosunku do cedentki - dwukrotnie rozporządzającej wierzytelnością - upadłość konsumencka. W konsekwencji zarządca (Insolvenzverwalter) złożył należącą do masy kwotę - ściągniętą od jej pracodawcy w depozycie sądowym. Do zaspokojenia ze środków zgromadzonych w masie upadłości dążył zarówno cesjonariusz niemiecki wnosząc powództwo, jak i instytucja kredytowa z siedzibą w Luksemburgu za pośrednictwem powództwa wzajemnego. Z perspektywy prawa niemieckiego pierwsza cesja była skuteczna, natomiast z punktu widzenia prawa luksemburskiego była ona 
Natomiast ochrona zapewniana przez absolutne środki publikacyjne również może okazać się iluzoryczna. I tak, C. Walsch zauważa, że istnieja również rejestry niedostępne dla szerszej publiczności ${ }^{50}$. Ponadto wpisy do takich rejestrów mają różne znaczenie, niekiedy konkuruja z innymi środkami zapewniajacymi jawność przelewu. Nadto wpisy do rejestru dostępne sa jedynie dla określonych podmiotów, lub też ich przedmiotem moga być jedynie pewne kategorie wierzytelności. Wreszcie przedmiotem takich rejestrów mogą być przelewy stanowiące „fragment" szerszego prawa zabezpieczającego całe przedsiębiorstwo dłużni$\mathrm{ka}^{51}$. Także „mechanizmy” - przewidziane w poszczególnych systemach prawnych - określające różne przejawy zawiadomienia dłużnika o przelewie - jak wskazano powyżej — różnią się względem siebie ${ }^{52}$.

Z kolei M.F. Müller opowiada się za szerokim ujęciem pojęcia „rzeczowe skutki przelewu"53. Także H. Labonté pojęciem tym obejmuje ogół materialnych postanowień obejmujących transfer „tytułu”, na podstawie których można ustalić, czy cesjonariuszowi przysługuje wierzytelność (all subsatntive provisions relating to the transfer of title that determines whether or not the assignee prevails over third partie vis-à-vis the (laim) ${ }^{54}$. Uważa on, że takim pojęciem należy objąć kwestie, czy wierzytelność „wyszła” z majatku cedenta, czy może stanowić ona przedmiot zaspokojenia dla wierzycieli cesjonariusza. Wreszcie uważa on, że także dłużnik ma interes w ustaleniu tego, kto jest jego wierzycielem, chociażby w sytuacji, w której w stosunku do cedenta przysługuje mu nadająca się do potrącenia wierzytelność wzajemna ${ }^{55}$.

\footnotetext{
— wskutek zaniechania zawiadomienia dłużnika — w myśl art. 1690 luksemburskiego $\mathrm{kc}$ - nieskuteczna.

${ }^{50}$ C. Walsh: The Role of Party autonomy..., s. 187.

${ }^{51}$ C. Walsh: The Role of Party autonomy..., s. 187.

${ }^{52}$ C. Walsh: The Role of Party autonomy..., s. 187.

${ }^{53}$ M.F. Müller: Drittwirkungen der Forderungsübetragung..., s. 526.

${ }^{54}$ H. Labontè: Third - Party effects..., s. 319-342.

${ }^{55}$ H. Labontè: Third - Party effects..., s. 327-328.
} 


\section{Wypowiedź TSUE z 9 października 2019 r. (C 548/18) i kalejdoskop zapatrywań głoszonych w doktrynie odnośnie do prawa właściwego dla skutków przelewu względem osób trzecich}

Przed laty Aldricus zauważył - trawestując rotę dawnej przysięgi sędziowskiej rozpoczynającej się od słów debet enim iudicare... ${ }^{56}-\dot{z ̇ e}$ należy stosować prawo bardziej „efektywne” i „pożyteczne” — (eam quae potior et utilior videtur $)^{57}$. Natomiast rozstrzygnięcie wydane przez TSUE z 9 października 2019 r. (C-548/18) nawiąuje jedynie do tradycyjnego kanonu interpretacyjnego prawa unijnego, czyli analizy celów przepisu, jego funkcjonalnego związku z innymi uregulowaniami oraz historii powstania określonej regulacji ${ }^{58}$. Wypowiedź ta nie przyniosła przełomu ${ }^{59}$, zamiast stanowić kres niepewności ${ }^{60}$ sędziowie z Luksemburga proklamowali - jako zasadę - niepewność prawa ${ }^{61}$. Sententia lata ${ }^{62}$ i sententia ferenda nie sa w tej wypowiedzi dostrzegalne, pomimo iż sądy w poszczególnych państwach członkowskich sa - przynajmniej w zakresie prawa prywatnego międzynarodowego - w dużym stopniu uzależnione od treści rozstrzygnięć TSUE ${ }^{63}$. Nie stanowi ono nawet „punktu orientacyjnego” pozwalającego na nawigacje po „cieśninie kolizyjnego prawa unijnego" ${ }^{64}$ pomiędzy Skylla rozwiązań nawiązujacych w zróżnicowa-

${ }^{56}$ G. Kegel: Internationales Privatrecht. 5. Aufl. München 1985, s. 94; Autor ten wspomina, iż w starożytnych Atenach sędzia składał przysięgę obligująca go do zastosowania - w przypadku luki w prawie - najsprawiedliwszego rozwiązania.

${ }^{57}$ P. Franzina, w: J. Basedow, G. Rühl, F. Ferrari, P. de Miguel Asensio (ed.) Encyclopedia - of - Private International Law..., s. 48-50.

${ }^{58}$ C. Sch mit: komentarz do orzeczenia TSUE..., s. 939.

${ }^{59}$ H.P. Mansell, K. Thorn, R. Wagner: Europäisches Kollisionsrecht..., s. 85119.

${ }^{60}$ D. Martiny, w: Münchener..., nb. 11.

${ }^{61}$ R. Freitag: Der Statut der Drittwirkungen einer Abtretung. LMK 2019, nr 424074; P. Mankowski: Komentarz..., s. 728.

${ }^{62}$ Zauważyć należy, iż niemalże przed trzydziestoma laty P. Lagarde, zauważył, iż art. 12 konw. rzymskiej o prawie właściwym dla zobowiązań umownych nie normuje zagadnienia skuteczności przelewu względem osob trzecich, tenże: Le nouveau droit international privé des contrats après l; entrée en vigueur de la convention de Rome du 19 junin 1980. Rev. crit. dr. int. pr 1991, n. 2, s. 335-336.

${ }^{63}$ D.P. Fernández Arroyo: Denationalising Private International Law..., s. 35.

${ }^{64}$ Próby podejmowane pod auspicjami Unii zmierzajace do rozwiązania tej problematyki wskazuja pośrednio na to, iż zwyciężyło zapatrywanie, iż chodzi tu o kwestię europejskiego prawa zobowiązań; odnośnie do przeciwnego zapatrywania zob. bliżej F. Bauer: Forderungsabtretung..., s. 103, s. 167, s. 301 i n. 
nym zakresie ${ }^{65}$ do kolizyjnoprawnej zasady autonomii woli ${ }^{66}$ a Charybda łącznika obiektywnego. Podkreślić należy, iż wśród tych pierwszych rozwiązań w grę może wejść jedynie statut wierzytelności ${ }^{67}$. Jego zwolennicy podkreślaja, że wierzytelność jako jednolita struktura podlegać może „zarówno w aspekcie jej zgaśnięcia, jak i zbycia tylko jednemu prawu”68, podkreślając przy tym zasadę jednolitego stosowania ${ }^{69}$, która i tak napotyka na przeszkody w postaci licznych kwestii czastkowych, takich np. jak prawo właściwe dla oceny zdolności prawnej i zdolności do czynności prawnych stron przelewu. Natomiast judykatura niemiecka dostarcza wielu przykładów zastosowania tego ujęcia ${ }^{70}$.

Podobnie jak to ma miejsce na obszarze innych niezwykle spornych obszarów prawa międzynarodowego prywatnego, idealne rozwiązania odnoszace się do sposobów poszukiwania prawa właściwego dla rzeczowych skutków przelewu nie istnieja $a^{71}$. Panaceum zapobiegającym tym trudnościom byłoby ujednolicenie krajowych uregulowań poświęconych przelewowi. Z drugiej strony — jak wskazuje przykład międz. pr. upadł. — jed-

${ }^{65}$ Unormowanie art. 10 ust. 2 holenderskiej ustawy z unormowaniu międzynarodowego prawa rzeczowego z 25.02.2008 r. (weszła ona w życie w dniu 1.05.2008 r.) nawiazujące w aspekcie prawa właściwego dla skutków przelewu względem osób trzecich do umowy zawartej pomiędzy stronami nie wchodzi w zasadzie w grę jako propozycja moga stanowić fundament dla przyszłej europejskiej regulacji, zobacz skrótowe uwagi w tym zakresie, T. Struycken, B. Sujecki: Das niederländische Gesetz zur Regeulung des internationalen Sachenrecht. IPRax 2008, z. 6, s. 558-562; zob. A. Kozioł: O nowym unormowaniu holenderskiego prawa prywatnego międzynarodowego. „Problemy Prawa Prywatnego Międzynarodowego" [dalej PPPM] t. 11, z. 141-153.

${ }^{66}$ C. Wals h: The Role of Party Autonomy..., s. 183.

${ }^{67}$ Interesujace jest to, iż $§ 14$ pochodzacego z 1881 r. projektu autorstwa Gebharda znalazł się przepis stanowiący: „Przelew wierzytelności podlega prawu państwa, które rozstrzyga o wierzytelności”; propozycja ta została skreślona — jako oczywista - podczas 693 sesji „Pierwszej Komisji”, zob. Ch. von Bar: Abtretung und Legalzession..., s. 467 , przyp. 24 i przyp. 25.

${ }^{68}$ M. Guldener: Zession, Legalzession und Subrogation im IPR. Zürich 1929, s. 23.

${ }^{69}$ R. Freitag: Verkauf und Zession und Zession hypothekarisch gesicherten Forderungen im Internationales Privatrecht. RIW 2005, z. 1, s. 29.

${ }^{70}$ Zobacz - pochodzace jeszcze sprzed wejścia w życie konw. rzymskiej o prawie właściwym dla zobowiązań umownych — orzeczenie niem. SN z 20 czerwca 1990 r. (VIII ZR 150/89) IPRax 2000, z. 2, s. 128, zob. bliżej A. Stadler: Der Streit um das Zessionsstatut - eine Endlose Geschichte?. IPRax 2000, s. 104-110; E.M. Kieninger: Globalzession und Eigemtumsvorbehalt im internationalen Rechtsverkehr. „Juristen Zeitung” [dalej JZ] 1999, z. 8, s. 404-410; ponadto porównaj — wpisujące się w nurt, podstawowej dla międzynarodowego prawa upadłościowego, zasady uniwersalizmu, której wyrazem jest współcześnie przyjęta przez art. 19 r.m.p.u. 2015/548 zasada automatycznego uznawania zagranicznych postępowań upadłościowych - orzeczenie niem. SN (Bundesgerichtshof) z 24 lutego 1994 r. (VII ZR 34/93), „Entscheidungen des Bundesgerichtshofes in Zivilsachen" [dalej BGHZ 125], poz. 22, s. 196-206.

${ }^{71}$ F. Bauer: Forderungsabtretung..., s. 292. 
nolita regulacja na płaszczyźnie prawa kolizyjnego ma znikomy wpływ na ujednolicenie prawa merytorycznego. Te pierwsze unormowania moga być źródłem dodatkowych wątpliwości, gdyż są oparte o założenie, że nieprzewidywalna niepewność wiążąca się z ogłoszeniem upadłości cedenta może być ujęta jako przewidywalne ryzyko ${ }^{72}$.

\section{Próba transpozycji pojęcia "główny ośrodek podstawowej działalności dłużnika" na obszar międzynarodowego prawa zobowiązań}

Współcześnie coraz większą ilość zwolenników ${ }^{73}$ znajduje łącznik siedziby cedenta rozumiany przez Autorów sprawozdania z 26 września 2016 r. w nawiązaniu do kryterium jego zwykłego pobytu ${ }^{74}$. W piśmiennictwie podnosi się szereg jego zalet ${ }^{75}$. I tak, zapewnia on pewność prawa w przypadku cesji globalnej przyszłych wierzytelności ${ }^{76}$, ponadto gwarantuje ochronę konkurujących z sobą wierzycieli, gdyż w przypadku wymogów publikacyjnych - przewidzianych przez wiele systemów prawnych - wierzyciel jest w stanie uzyskać wiedzę o unormowaniach obowiązujących w siedzibie cedenta, i w ten sposób podjać starania zmierzające do ochrony swych uprawnien. Wreszcie kryterium to nawiązuje do art. 22 konw. nowojor. o cesji ${ }^{77}$. Także ujęty w postanowieniach rozdziału

${ }^{72}$ C. Thomale: Das Mittelpunkt der hauptsächlichen Interessen bei Gesellschaftsinsolvenzen mit Auslandsberührung. IPRax 2018, z. 3, s. 257.

${ }^{73}$ E.M. Kieninger: Das auf die Drittwirkungen..., s. 3353; C. Walsh: The Role of Party Autonomy..., s. 181 i n.

${ }^{74}$ COM 2016 (626) final, s. 12.

${ }^{75}$ E.M. Kieninger, E. Schütze: Die Forderungsabtretung im Internationalen Privatrecht. IPRax 2005, z. 3, s. 200-208.

${ }^{76}$ M. Pazdan: Przelew wierzytelności..., s. 132-134.

${ }^{77}$ Wedle tej normy - noszącej „nagłówek” prawo właściwe dla konkurujacych uprawnien: (law applicable to competing rights) — „With the exception of matters that are settled elsewhere in this Convention and subject to articles 23 and 24, the law of the State in which the assignor is located governs the priority of the right of an assignee in the assigned receivable over the right of a competing claimant", wedle polskiego przekładu - dokonanego przez W. Kurowskiego - norma ta brzmi; „Z wyjątkiem kwestii uregulowanych innymi postanowieniami niniejszej konwencji oraz z zastrzeżeniem art. 23 i art. 23 (niniejszej konwencji), prawo państwa, w którym cedent ma swą siedzibę, jest właściwe dla oceny pierwszeństwa prawa cesjonariusza do wierzytelności stanowiącej przedmiot przelewu przed prawem osoby występującej z konkurencyjnym roszczeniem". W. Kurowski: Przelew wierzytelności w handlu..., s. 1133-1193. 
VIII prawa modelowego - nawiązujących do koncepcji jedności zabezpieczenia i jego funkcjonalnego ujęcia ${ }^{78}$ - UNICITRAL o „czynnościach zabezpieczających" (Model Law on Secured Transactions) ${ }^{79}$ z 2016 r. art. 86, określa łacznik siedziby „dającego zabezpieczenie” (grantor) ${ }^{80}$. Podkreślić należy, iż zbywca wierzytelności znajduje się w „centrum” swoistej konstrukcji prawnej, jaka stanowi przelew. Kryterium to było rozważane już in statu nascendii prac nad kodyfikacją europejskiego międzynarodowego prawa zobowiązań ${ }^{81}$. Pomimo swej wieloznaczności ${ }^{82}$ oraz potencjalnego niebezpieczeństwa wiążącego się z jego przyjęciem w postaci ograniczenia unijnej swobody przedsiębiorczości ${ }^{83}$ stanowi „pomost" łaczacy regulacje międzynarodowego prawa zobowiązań z unormowaniami międz. praw. upadł ${ }^{84}$. Nawiązują do niego także prawodawcy

${ }^{78}$ C. Heinze, C.J. Warmuth: The law applicable..., s. 821.

${ }^{79}$ Uncitral Model Law on Secured Transactions, Vienna 2019.

${ }^{80}$ Wedle tej normy: „Except provided in articles 87 and 97-100, the law applicable to the creation, effectivness against third parties and priority of a security right in an intangible asset is the law of the State in which grantor is located".

${ }^{81}$ Zobacz art. 16 ust. 2 przedprojektu konwencji rzymskiej pochodzacego z 1972 r.; O. Lando, B. v. Hoffmann, K. Siehr: European Private Law of Obligations 1975. Tekst tej normy w języku francuskim podany został na s. 224 tego opracowania, natomiast przekład angielski znajduje się na s. 235; Natomiast E.M. Kieninger zwraca uwagę na wniosek delegacji irlandzkiej i duńskiej, zmierzający do skreślenia tej normy, w którym podkreślono nieprzystawalność łącznika prawa właściwego dla wierzytelności do potrzeb międzynarodowego prawa upadłościowego, taż: Forderungsabtretungsstatut im Verhältniss zu Dritten. RabelsZ 1998, t. 62, z. 4, s. 690.

${ }^{82}$ W. Klyta: Spótki kapitałowe $w$ prawie prywatnym międzynarodowym. Kraków 2002, s. 25-34; A. Flessner: Privatautonomie und Interessen..., s. 555.

${ }^{83}$ A. Flessner: Privatautonomie und Interessen..., s. 555.

${ }^{84} \mathrm{~F}$. Bauer, twierdząc, iż problematyka prawa właściwego dla rzeczowych skutków przelewu wykracza poza zakres materii europejskiego prawa zobowiązań, proponuje w przyszłym rozp. unijnym poświeconym międz. prawu rzeczowemu (jednak de lege lata brakuje Unii kompetencji ustawodawczej w dziedzinie prawa rzeczowego) lub ogólnym rozp. normującym całokształt europejskiego prawa pryw. międz. - przyjęcie rozbudowanej regulacji. Na jej czele stać winna norma „posiłkowa” o brzmieniu: „Relacja pomiędzy cedentem i cesjonariuszem podlega prawu rządzącemu tym stosunkiem”; w dalszej kolejności następuje zasadnicze unormowanie stanowiące: „Przesłanki i skutki zbycia wierzytelności w stosunku do osób trzecich wraz z unormowaniami odnoszącymi się do formy tego zbycia podlegają prawu państwa, w którym podmiot uprawniony w pełni do wierzytelności (Vollrechtsinhaber) ma swój główny ośrodek podstawowej działalności. W przypadku, w którym ustalenie tego kryterium jest niemożliwe należy stosować prawo państwa, w którym podmiot uprawniony w pełni do wierzytelności (Vollrechtsinhaber) ma miejsce swego zwykłego pobytu. W przypadku spółki, stowarzyszenia lubi osoby prawnej za miejsce zwykłego ich pobytu należy przyjąć miejsce ich rzeczywistej siedziby”. Wreszcie F. Bauer proponuje normę chroniącą dłużnika o interesującej treści: „Prawo państwa, któremu podlega wierzytelność stanowiąca przedmiot przelewu określa w jakim zakresie treść i zakres wierzytelności ulega zmianie wskutek przelewu, w szczególności temu prawu podlegają zarzuty, które może dłużnik kierować przeciwko nowemu wierzycielo- 
w niektórych państwach członkowskich Unii ${ }^{85}$, jak i sądy w państwach należących do Europejskiego Obszaru Gospodarczego ${ }^{86}$. Pojawia się zatem pytanie, czy podstawowe pojęcie międz. pr. upadł., jakim jest działalności główny ośrodek podstawowej dłużnika ${ }^{87}$, jest na tyle precyzyjne aby zapewnić ochronę wierzycieli cedenta w przypadku jego upadłości ${ }^{88}$. Punktem wyjścia dla dalszych rozważań jest stwierdzenie Pierwszego

wi. Ponadto prawo to określa przesłanki przy zaistnieniu których niezależnie od prawa wskazanego w ustępie poprzedzającym dłużnik może „potraktować” nieuprawnionego jako wierzyciela a wierzyciela jako nieuprawnionego". Kolejny fragment propozycji dotyczy problematyki zmiany statutu. I tak: „Przeniesienie głównego ośrodka podstawowej działalności do innego państwa nie ma wpływu na prawa na wierzytelności powstałe przed przeniesieniem. Nie mogą one być wykonywane w sprzeczności nowym prawem". W końcu Autor ten definiuje pojęcie „przeniesienia wierzytelności”; w konsekwencji wedle jego propozycji: „Pojęcie przeniesienie obejmuje nieograniczone przeniesienie wierzytelności włącznie $\mathrm{z}$ ich przeniesieniem na zabezpieczenie jak również skuteczne względem osób trzecich częściowe przeniesienie wierzytelności”; tenże: Forderungsabtretung..., s. 305-306; propozycja ta zyskała akceptację ze strony F.J. Sonnenbergera, tenże: Randbemerkungen..., s. 230-231; zauważyć należy, iż zmierzająca w tym samym kierunku idea została zgłoszona przed laty przez W. Kurowskiego, i tak: wedle normy proponowanej przez tego Autora: 1) „Przelew wierzytelności podlega prawu państwa, w którym cedent ma, w chwili zawarcia umowy siedzibę albo miejsce zwyczajnego pobytu. Temu samemu prawu podlega ocena skuteczności przelewu względem osób trzecich. 2) Prawo, któremu podlega przenoszona wierzytelność, rozstrzyga o dopuszczalności jej przelewu, przesłankach skuteczności przelewu wobec dłużnika oraz stosunkach pomiędzy cesjonariuszem a dłużnikiem", tenże: Przelew wierzytelności w prawie prywatnym międzynarodowym. Kraków 2005, s. 250, propozycja ta zyskała akceptację ze strony M. Pazdana, tenże: Zagadnienia kolizyjnoprawne..., s. 893, przyp. 20.

${ }^{85}$ Zobacz art. $87 \S 3$, zd. 1 belgijskiego kodeksu prawa prywatnego międzynarodowego z 16 lipca 2004 r., Mon. belg z 27.07.2004 r., s. 57344-57374, zobacz angielski przekład tego przepisu autorstwa C. Clijmans i P. Toremansa, opubl. RabelsZ 2007, t. 70, s. $358-397$.

${ }^{86}$ K. Lillehot: Norwegian Supreme..., s. 539 i n.

${ }^{87}$ Kryteria określone zarówno w art. 19 rozp. Rzym I, jak i art. 3 r. m.p.u. 2015/848 prowadzą w zasadzie do tych samych rezultatów; przy czym łącznik miejsca siedziby głównego organu zarządzającego spółek i innych osób prawnych, jak również podmiotów nieposiadających osobowości prawnej określony w art. 19 pkt 1 rozp. Rzym I został przez twórców r.m.p.u. 2015/848 odzwierciedlony w inny sposób, mianowicie za pośrednictwem domniemania, że rzeczywista siedziba określona jako główny ośrodek podstawowej działalności znajduje się w państwie ich utworzenia (czyli w państwie ich siedziby statutowej); w konsekwencji prawodawca dopuszcza sytuacje, w której spółka przenosi w określonych ramach czasowych - swą siedzibę do innego państwa w celu skorzystania z obowiąujaccych tam regulacji prawa upadłościowego.

${ }^{88}$ T.C.H $\mathrm{H}$ tley: Choice of law regarding the voluntary assignment of contractual obligations under the Rome I Regulation. „The international \& Comparative Law Quaterly” [dalej ICLQ] 2011, Nr 1, s. 48-49; Autor ten zauważa, że pojęcie „dłużnik” może wskazywać na dłużnika wierzytelności stanowiącej przedmiot przelewu, jednakże w dalszych rozważaniach pod tym pojęciem będzie rozumiany niewypłacalny cedent. 
Rzecznika Generalnego TSUE M. Szpunara. Rzecznik ten podkreślił na kartach - przedstawionej w dniu 2 marca 2017 r. (C-54/16) w sprawie Vinyls Italia $S p A$, w upadłości, przeciwko Mediterranea di Navigazione $\operatorname{SpA}$ - opinii, że nieoceniona pomoca przy dokonywaniu wykładni r.m.p.u. 1346/2000 sa uwagi poczynione w pochodzacym z 3 maja $1996 \mathrm{r}$. raporcie M. Virgósa i E. Schmit, który dotyczy wprawdzie fundamentu dla europejskiego międz. pr. upadł. w postaci konwencji w sprawie postępowania upadłościowego ${ }^{89}$, niemniej jednak powszechnie, w doktrynie uznaje się go za źródło wartościowych wskazówek dotyczących interpretacji przepisów rozporządzenia. Wskazane opracowanie zachowuje pełną aktualność pod rządami r.m.p.u. 2015/84890. Twórcy tego dokumentu zauważyli, że upadłość to przewidywalne ryzyko, w konsekwencji istotne znaczenie ma przyjęcie takich obiektywnych łączników jurysdykcyjnych, które moga zostać z łatwością ustalone przez wierzycieli upadłego. Umożliwi to przewidywalność ryzyka wiążącego się z upadłością ${ }^{91}$. Po upływie niemalże ćwierćwiecza współczesna judykatywa nadal zmaga się z niepewnością wiążąca się z interpretacją pojęcia główny ośrodek podstawowej działalności dłużnika ${ }^{92}$. W tym miejscu przytoczyć należy fragment rozbudowanej normy określonej w art. 3 r.m.p.u. 2015/848. I tak, zgodnie art. 3 ust. 1 in fine tego aktu, „głównym ośrodkiem podstawowej działalności" (znajdującym się na obszarze Unii z wyjątkiem Danii) jest miejsce, w którym dłużnik regularnie zarządza swoją działalnością o charakterze ekonomicznym i które ,jako takie” jest rozpoznawalne dla osób trzecich" ${ }^{\prime 3}$. W dalszej kolejności norma ta określa trzy presumpcje odnoszące się zarówno do spółek i osób prawnych, jak i osób

${ }^{99}$ Dz.U. N. L 6500/96; akt ten został otwarty do podpisu w Brukseli w dniu 23 listopada 1995 r. i podpisany przez przedstawicieli dwunastu państw członkowskich Unii.

${ }^{90}$ Zobacz stwierdzenie określone w tezie nr 41 Opinii Rzecznika Generalnego TSUE w sprawie (C-54/16) Vinyls Italia SpA, w upadłości, przeciwko Mediterranea di Navigazione $\operatorname{SpA}$.

${ }^{91}$ Tekst powyższego opracowania zamieszczony jest w postaci załącznika nr 3 w opracowaniu komentarzowym: R. Bork, K. van Zwieten (Edit.), Commentary On The European Insolvency Regulation. Oxford 2016, s. 817-875.

${ }_{92}$ Zobacz orzeczenie Sąu Krajowego (Landesgericht) w Berlinie z 8.01.2018 r. (84 T 2/18). IPRax 2018, z. 3, s. 271—274, ten judykat zapadł na tle następującego stanu faktycznego: spółka z o.o. prowadząca przedsiębiorstwo lotnicze o firmie „Niki” z siedzibą statutową we Wiedniu złożyła wniosek o upadłość do sądu niemieckiego powołując się na okoliczność, że jej główny ośrodek podstawowej działalności znajduje się w innym państwie niż państwo jej statutowej siedziby. Sąd niemiecki stwierdził, iż okoliczności pozwalające na obalenie podstawy domniemania nie zostały uprawdopodobnione. W konsekwencji próba ochrony przed forum shopping - o którym mowa w punktach 29 i 30 preambuły do r.m.p.u. 2015/848 ze strony upadłej spółki okazała się nieudana.

${ }^{93}$ Zauważyć należy, iż swoista technika polegająca na „inkorporacji” niejasnej tezy nr 13 preambuły do r.m.p.u. 1346/2000 do przepisu art. 3 ust. 1 wersji przekształco- 
fizycznych. Te ostatnie podmioty podzielone zostały na dwie kategorie. I tak, w pierwszej z nich znaleźli się przedsiębiorcy, natomiast w drugiej konsumenci. Jak dotychczas nie sformułowano powszechnie akceptowanych dyrektyw autonomicznej wykładni kryterium głównego ośrodka podstawowej działalności dłużnika ${ }^{94}$. Jego istota — nawet jeżeli przy jego interpretacji należy uwzględniać dodatkowe czynniki ${ }^{95}$ - tkwi w koncepcji rzeczywistej siedziby spółki rozumianej jako miejsce, w którym podstawowe decyzje zarządu spółki sa realizowane podczas jej codziennej działalności. W tym miejscu należy przytoczyć argument zgłoszony przez F. Bauera, który zauważył, iż wówczas gdy cesjonariusz - powołujący się na skuteczny przelew — jest uprawniony do żądania „oddzielenia” od masy upadłości cedenta przysługującej mu wierzytelności dojdzie do „uzgodnienia ze sobą" statutu, któremu podlega zbycie wierzytelności i statutu upadłościowego ${ }^{96}$. Ograniczy to konieczność dokonania zabiegów kwalifikacyjnych. Jednakże dodać należy, że źródłem dodatkowych trudności interpretacyjnych jest wskazane wyżej domniemanie, w myśl którego prawodawca unijny zakłada „zgodność” podstawowego łącznika międz. pr. upadł. z statutową siedzibą spółki ${ }^{97}$. W konsekwencji, wyklu-

nej r.m.p.u. 2015/848 osłabia domniemanie, iż główny ośrodek podstawowej działalności spółki lub osoby prawnej znajduje się w miejscu jej siedziby statutowej.

${ }^{94}$ Zobacz np. tezę nr 33 uzasadnienia do wyroku TSUE z dnia 2 maja 2006 r. w sprawie (C-341/04) Eurofood IFSC Ltd; Sąd w Luksemburgu ograniczył się do transpozycji, przytoczonych powyżej, stwierdzeń M. Virgósa i E. Schmit; zobacz także: wyrok TSUE z dnia 20 października 2011 r. w sprawie C-396/0, w postępowaniu: Interedil Srl, w likwidacji, przeciwko Fallimento Interedil Srl, Intesa Gestione Crediti SpA, wyrok TSUE z dnia 15 grudnia 2011 r. w sprawie C-191/10 Rastelli Davide e C. snc przeciwko Jean-Charles'owi Hidouxowi, działajacemu w charakterze syndyka masy upadłości spółki Médiasucre international; współcześnie przedmiotem zainteresowania TSUE jest konstrukcja vis attractiva concursus, zob. wyrok TSUE z dnia 4 grudnia 2019 r. w sprawie C-493/18 w postępowaniu UB przeciwko VA, Tiger SCI, WZ, w charakterze syndyka masy upadłości UB, Banque patrimoine et immobilier $S A$; interesujacy jest również wyrok TSUE z 18 września 2019 r. w sprawie C-47/18 w postępowaniu Skarb Państwa Rzeczypospolitej Polskiej - Generalny Dyrektor Dróg Krajowych i Autostrad przeciwko Stephanowi Rielowi, występującemu w charakterze zarządcy tymczasowego majątku Alpine Bau GmbH.

${ }^{95}$ F. Bauer: Forderungsabtretung..., s. 288; wśród dalszych czynników wskazać należy na siedziby strategicznych klientów dłużnika, statuty, którym podlegają umowy o pracę zatrudnianych przez spółkę pracowników, miejsce, w którym znajdują się biura spółki, miejsce działania organów nadzorujących spółkę.

${ }^{96}$ E. Bauer: Forderungsabtretung..., s. 287.

${ }_{97}$ Swoista - niesprzyjająca — pomimo deklaracji prawodawcy określonej w tezach nr 29 i nr 30 preambuły do r.m.p.u. 2015/848 - pewności prawa regulację — określa art. 3 ust.1 pkt. 1. r. m.p.u. 2015/848; w myśl tej normy: „w przypadku spółki lub osoby prawnej domniemywa się, wobec braku dowodu przeciwnego, że głównym ośrodkiem ich podstawowej działalności jest miejsce siedziby statutowej. Domniemanie takie ma zasto- 
czając skrajne przypadki „zmiany szaty prawnej spółki”98, można liczyć się z sytuacjami, w których działalność spółki skoncentrowana będzie zarówno w miejscu jej siedziby statutowej oraz w innych miejscach. Wówczas pomimo widocznej - w świetle najnowszych zmian legislacyjnych — tendencji do jej osłabienia nadal funkcjonować będzie powyższa presumpcja, co w istocie doprowadzi do „lokalizacji” głównego ośrodka podstawowej działalności dłużnika w miejscu statutowej siedziby spółki. Powyżej wskazane orzeczenie Sądu Krajowego (Landesgericht) w Berlinie z 8 stycznia 2018 r. (84 T 2/18) wskazuje, iż nawet duże spółki dysponujace fachowym doradztwem prawnym nie są w stanie przewidzieć tego potencjalnego systemu prawnego rządzacego ich upadłością (statutu upadłościowego). W świetle powyższych stwierdzeń blask kryterium głównego ośrodka podstawowej działalności cedenta nieco przygasa.

$\mathrm{Na}$ marginesie zauważyć należy, że słabości tego rozwiąania ujawniają się również w przypadku, gdy jedna wierzytelność przysługuje kil$\mathrm{ku}$ wierzycielom majacym siedziby w różnych państwach, a w myśl postanowień prawa państwa, któremu podlega wierzytelność, muszą oni działać wspólnie ${ }^{99}$.

\section{Pogranicze międzynarodowego prawa rzeczowego i europejskiego międzynarodowego prawa upadłościowego}

Zespolenie skutków obligacyjnych i rzeczowych w jednolitej konstrukcji przelewu określane jest $\mathrm{w}$ doktrynie za pośrednictwem metafory „dwóch stron tego samego medalu” ${ }^{100}$. W konsekwencji immanentnym

sowanie tylko wtedy, gdy siedziba statutowa nie została przeniesiona do innego państwa członkowskiego w okresie trzech miesięcy poprzedzających złożenie wniosku o wszczęcie postępowania upadłościowego".

${ }_{98}$ Zobacz orzeczenie TSUE z 25 października 2017 r. (C-106/16) w sprawie „Polbud”, krytycznie odnośnie do tej wypowiedzi odniósł się A. Wowerka, tenże: Kolizyjnoprawne transgraniczne przekształcenie spótki a przeniesienie siedziby spótki. Kolizyjnoprawna zasada jednoczesnego stosowania prawa wtaściwego dla spótki przeksztatcanej i prawa państwa spótki docelowej (zasada kombinacji, zjednoczenia). Przeniesienie siedziby spótki i zmiana statutu personalnego spótki. „Gdańskie Studia Prawnicze Przegląd Orzecznictwa” 2018, nr 4, s. 53-66.

${ }^{99}$ F. Bauer: Forderungsabtretung..., s. 290.

${ }^{100}$ A. Flessner: Privatautonomie und Interessen..., s. 543; natomiast w dawniejszej doktrynie austriackiej rozważano również analogiczne stosowanie statutu rzeczowego w kwestii wskazania prawa właściwego dla przelewu, zob. - pochodzące sprzed wej- 
ograniczeniem regulacji określonej art. 14 rozp. Rzym I sa postanowienia w międzynarodowego prawa rzeczowego, a ściślej rzecz ujmując regulacje określające „los” zabezpieczeń rzeczowych w przypadku upadłości cedenta ${ }^{101}$. W tym miejscu pojawia się swoista kwestia wstępna w postaci zagadnienia, jaki podmiot nabył skutecznie wierzytelność, która jest konieczna do rozstrzygnięcia kwestii głównej, która stanowi ochrona wierzycieli cedenta przewidziana przez - wyznaczone normami kolizyjnymi międz. pr. upadł - merytoryczne unormowania prawa upadłościowego ${ }^{102}$. Jak zauważył R. Freitag, w przypadku przelewu na zabezpieczenie, jak również innych zabezpieczeń mogących obciążać wierzytelność, takich jak np. zastaw na wierzytelności, należy uwzględnić uregulowanie określone w art. 8 r.m.p.u. 2015/848 ${ }^{103}$. Wskazane unormowanie należy do najbardziej spornych regulacji europejskiego międz. pr. upadł. ${ }^{104}$. Stanowiło zatem przedmiot zainteresowania Rzecznika Generalnego TSUE M. Szpunara. Autor ten nawiązał do dominującego w doktrynie poglądu. Wyrazem jego stanowiska sa: opinia z 27 listopada 2014 r. w sprawie H. Lutz v. E. Bäurle (C-557/13), jak również stanowiąca rozwinięcie wcześniej wyrażonych myśli - opinia z 26 maja 2015 r. (C-195/15) w sprawie SCI Senior Home v. Gemeinde Wedemark Hannoversche Volksbank e $G^{105}$. Według art. 8 r.m.p.u. 2015/848 in fine: „otwarcie postępowania upadłościowego nie narusza (shall not affect, nicht berürht) praw rzeczowych przysługujących wierzycielowi lub osobie trzeciej na rzeczach lub prawach znajdujących się w chwili otwarcia postępowania w innym państwie członkowskim"106. Celem tej normy jest ochrona wierzycieli i osób trzecich przed nieprzewidziana przez statut rzeczowy daleko posuniętą ingerencją ze strony statutu upadłościowego $\mathrm{w}$ istotę danego zabezpieczenia rzeczowego. Rozwiązanie to powinno się przyczynić - zdaniem jego twórców - do uproszczenia i przyspieszenia toku międzynarodowego postępowania upadłościowego. Niestety najważniejszą zaletą tego ujęcia jest jego prostota (simplicity of formula, règle

ścia w życie konw. rzymskiej — orzeczenia Sądu Krajowego (Landesgericht) w Insbrucku z 10.09.2004 r. oraz Wyższego Sądu Krajowego (Oberlandesgericht) z 4.01.2005 r, w Insbrucku a także austriackiego SN (Oberstes Gericht) z 8. 03. 2007 r. „Zeitschrift für Rechtsvergleichung" [dalej ZfRV] 2007, z. 2, s. 78-80, wraz z glosą H. Offnera, tamże, s. 80.

${ }^{101}$ F. Bauer: Forderunsabtretung..., s. 94.

${ }^{102}$ F. Bauer: Forderungsabtretung..., s. 94.

${ }^{103}$ R. Freitag: Der Statut der Drittwirkungen einer Abtretung. LMK 2019, nr 424074.

${ }^{104}$ W. Klyta: Uznanie..., s. $136-152$.

${ }^{105}$ W. Klyta: Uznanie..., s. 148-152.

${ }^{106}$ Należy zauważyć, iż w istocie przepis ten wyraża następującą normę: „prawo państwa, w którym otwarto postępowanie upadłościowe nie narusza praw rzeczowych”. 
pur et simple). W dawniejszej doktrynie sporny był charakter tego uregulowania ${ }^{107}$. Niektórzy sądzili, iż stanowi ono swoistą normę kolizyjną ${ }^{108}$. $\mathrm{Z}$ zastosowanego w tym przepisie sformułowania „nie narusza” wynika, iż uprawnienia przysługujace wierzycielowi mogą zostać ograniczone przez postanowienia prawa upadłościowego obowiązujące w państwie, w którym znajduje się obciążona rzecz ${ }^{109}$. Przyjęcie tego zapatrywania przyczynić się może do przyspieszenia postępowania upadłościowego i ułatwienia zarządu masa upadłości ${ }^{110}$. Jednakże według dominującego - wzmocnionego powyżej wskazanymi współczesnymi wypowiedziami TSUE - pogląd art. 8 r.m.p.u. 2015/848 jest przepisem o charakterze materialnym. Jego znaczenie wyraża się w tym, iż przysługujące wierzycielom zabezpieczenie nie podlega jakimkolwiek ograniczeniom — ani ze strony statutu upadłościowego, ani prawa upadłościowego państwa, w którym jest ono położone ${ }^{111}$. Dodać należy, że za poglądem tym przemawiają również dyrektywy wykładni systemowej. Przepis art. 8 r.m.p.u. 2015/848 jest inaczej sformułowany niż pozostałe normy kolizyjne — przewidziane w obydwu wersjach rozporządzenia o międzynarodowym postępowaniu upadłościowym. Brakuje w nich łącznika wskazującego prawo właściwe. M. Virgós i E. Schmit wyrazili zapatrywanie, iż zagraniczne postępowanie główne nie prowadzi do ograniczenia uprawnień wierzycieli, którym przysługuja zabezpieczenia ${ }^{112}$. Praktyczna konsekwencją tego poglądu jest to, iż wierzyciel, któremu przysługuje zabezpieczenie rzeczowe, może - pomimo otwarcia za granica postępowania upadłościowego, którego skutki ulegają nieograniczonemu rozszerzeniu na obszar innego państwa - zaspokoić się z obciążonego przedmiotu zgodnie z przepisami obowiązującymi w państwie położenia rzeczy. Natomiast bez znaczenia jest to, czy takie uprawnienie przysługuje mu w myśl postanowień statutu upadłościowego ${ }^{113}$. Uprawnienie wierzyciela, któremu przysługuje

${ }^{107}$ Podkreślić należy, iż treść art. 5 r. m.p.u. (normującego los zabezpieczeń rzeczowych w przypadku upadłości) 1346/2000 została przejęta — bez jakiejkolwiek modyfikacji - do art. 8 r.m.p.u. 2015/848.

${ }^{108}$ Należy zdecydowanie przeciwstawić się - występującemu niekiedy w doktrynie - określeniu „negatywna norma kolizyjna” (negative conflict rule). Stanowi ona pewien skrót myślowy podkreślający, że art. 5 r.m.p.u. 1346/2000 (art. 8 r.m.p.u. 2015/848 nie wskazuje prawa właściwego dla zabezpieczeń rzeczowych, a jedynie wyklucza stosowanie statutu upadłościowego w tej mierze; jednakże do tego określenia nawiązuje M. Szpunar w pkt. 31 swej opinii sporządzonej w sprawie SCI Senior Home v. Gemeinde Wedemark Hannoversche Volksbank eG (C-195/15).

${ }^{109}$ W. Klyta: Uznanie..., s.149.

${ }^{110}$ W. Klyta: Uznanie..., s. 149

${ }^{111}$ W. Klyta: Uznanie..., s. 149.

112 Tekst powyższego opracowania zamieszczony jest w postaci załącznika nr 3 w opracowaniu R. Bork, K. van Zwieten (Edit.): Commentary..., s. 817-875.

${ }^{113}$ W. Klyta: Uznanie..., s. 150. 
zabezpieczenie rzeczowe, ma więc pierwszeństwo przed uprawnieniami wierzycieli cedenta. Oczywistością jest stwierdzenie, iż prawo rzeczowe powinno zostać przed otwarciem postępowania prawidłowo ustanowione. Zagadnienie to podlega ocenie na podstawie prawa właściwego dla oceny skuteczności przelewu wskazanego przez normy kolizyjne obowiąujące $\mathrm{w}$ siedzibie sądu orzekającego ${ }^{114}$. Statut właściwy dla oceny rzeczowych skutków przelewu rozstrzyga również o pierwszeństwie praw rzeczowych obciążających tę samą wierzytelnośćc ${ }^{115}$. Natomiast podkreślić trzeba, że o „losach” praw rzeczowych ustanowionych przez zarządcę na wierzytelnościach należących do masy upadłości po otwarciu postępowania rozstrzyga statut upadłościowy wyznaczony łacznikiem głównego ośrodka podstawowej działalności dłużnika ${ }^{116}$. Przepis art. 8 r.m.p.u. 2015/848 nie definiuje pojęcia „prawo rzeczowe” (right in rem, dingliches Recht). $\mathrm{W}$ trakcie prac kodyfikacyjnych rozważano wiele definicji jednak każda $\mathrm{z}$ nich okazywała się z różnych przyczyn nietrafna ${ }^{117}$. W doktrynie postuluje się, iż pożądane jest wykorzystywanie założeń kwalifikacji autonomicznej ${ }^{118}$. Nie ma znaczenia czy prawo rzeczowe obciąża, prawo w tym wierzytelność jak również zbiór rzeczy i praw o zmiennym składzie ${ }^{119}$. W postanowieniu art. 8 ust. 2 r.m.p.u. 2015/848 przewidziano wskazówkę interpretacyjną pomocną przy dokonywania tych zabiegów kwalifika-

114 Zauważyć należy, iż w przypadku, gdy kontrahent dłużnika będzie w dobrej wierze co do jego uprawnienia do zarządu i rozporządzania majątkiem, prawo rzeczowe powstałe po otwarciu postępowania będzie korzystało z ochrony określonej tym przepisem.

${ }^{115}$ W. Klyta: Uznanie..., s. 150.

116 Zagadnienia wiążące się z ustaleniem składu masy normuje wyrażający regułę lex fori concursus art. 7 r.m.p.u. 2015/848. Bliższe wskazówki w tym zakresie określa art. 7 ust. 2 lit. „b” tego aktu - zobacz rozważania odnoszące się do wcześniejszej wersji tej normy określonej w art. 4 r.m.p.u. 1346/2000 - W. Klyty, tenże Uznanie..., s. 124-126; wydaje się, że pewnym nieporozumieniem przyrównywanie przepisów międzynarodowego prawa upadłościowego do norm wymuszajacych swe zastosowanie, zob. T. Pfeiffer: Article 4 EIR: Applicability of the Law of the State of the Opening of the Proceedings. w: B. Hess, Burkhard, P. Oberhammer, T. Pfeiffer, (Hrsg.): European Insolvency Law: The Heidelberg-Luxembourg-Vienna Report on the Application of Regulation No. 1346/2000/EC on Insolvency Proceedings, München 2014, pp. 168-177.

${ }^{117}$ W. Klyta: Uznanie..., s. 150.

${ }^{118}$ W. Klyta: Uznanie..., s. 150; jednakże współczesne wypowiedzi doktryny w tym zakresie nasycone sa jedynie wattkami praktycznymi, zob. R. Snowden, w: R. Bork, K. van Zwieten (Edit.), Commentary..., s. 238-252.

${ }^{119}$ Odnośnie do problematyki zabezpieczenia określanego jako floating charge - zob. szerzej L. Collins, Floating Charge. Receivers and Managers and the Conflict of Law. ICLQ 1978, t. 27, 691-710; pojęcie „zbioru nieokreślonych przedmiotów” jest niezrozumiałe - zarówno dla prawnika angielskiego — jak i interpretatora art. 8 r.m.p.u. pochodzącego z kręgu systemów prawa stanowionego, zob. R. Snowden, w: R. Bork, K. van Zwieten (Edit.), Commentary..., s. 244. 
cyjnych $^{120}$. Prawo rzeczowe w rozumieniu wskazanego przepisu powinno charakteryzować się dwoma cechami. Po pierwsze: musi istnieć ścisły związek pomiędzy tym prawem a obciążoną rzeczą (prawem), po drugie: wierzycielowi powinno przysługiwać skuteczne względem osób trzecich uprawnienie do zaspokojenia się z rzeczy (prawa). Niektórzy uważaja, iż pojęcie „prawo rzeczowe” powinno być interpretowane w sposób zawężajaccy. Natomiast według art. 8 ust. 3 r.m.p.u. 2015/848 prawo wpisane do publicznego rejestru i skuteczne względem osób trzecich, na mocy którego można domagać się od osoby trzeciej prawa rzeczowego, jest zrównane z uprawnieniem wynikajacym $\mathrm{z}$ art. 8 ust. 1 r.m.p.u. 2015/848 ${ }^{121}$. W doktrynie za prawa rzeczowe uznaje się: prawa zastawnicze na wierzytelności, przelew na zabezpieczenie oraz użytkowanie wierzytelności ${ }^{122}$. Jedynie porządkujacy charakter ma uwaga poczyniona przez C. Heinze oraz C.J. Warmuth ${ }^{123}$, że sam przelew wierzytelności nie stanowi prawa rzeczowego w rozumieniu wskazanej normy. W konsekwencji to samo prawo rządzi postępowaniem upadłościowym i rozstrzyga o rzeczowych skutkach przelewu co ułatwi zarząd masą upadłości.

Niektórzy sądzą, iż na mocy tego przepisu wierzyciel może zatrzymać nadwyżkę pozostałą po zaspokojeniu wierzytelności, z wierzytelności stanowiącej przedmiot zabezpieczenia, jeśli zezwala mu na to prawo, któremu podlega dana wierzytelnośćc ${ }^{124}$. Natomiast TSUE - zainspirowany wyżej określona opinią Rzecznika Generalnego M. Szpunara w orzeczeniu z 26 października 2016 r. w sprawie SCI Senior Home v. Gemeinde Wedemark Hannoversche Volksbank eG (C-195/15) zauważył, że istota prawa rzeczowego $\mathrm{w}$ rozumieniu tego przepisu jest to, że podmiot, którego rzecz lub prawo obciąża dane zabezpieczenie rzeczowe musi w istocie znosić egzekucje ze strony wierzyciela, któremu przysługuje powyższe prawo ${ }^{125}$.

${ }^{120}$ Wydaje się, że norma ta przewiduje „typologiczny” opis cech charakterystycznych prawa rzeczowego, w związku z tym poszczególni krajowi prawodawcy nie mają zatem „pełnej” swobody w określaniu katalogu praw rzeczowych. Wprowadzenie nowego typu prawa rzeczowego nie może zatem odbywać się w zupełnym oderwaniu od treści art. 8 ust. 2 r.m.p.u. $2015 / 848$.

${ }^{121}$ Przepis ten rozszerza katalog praw rzeczowych i jest koniecznością ochrony bezpieczeństwa obrotu, jako przykład tego prawa może służyć prawo zabezpieczające na majątku spółki w postaci unormowanej postanowieniami angielskiego Companies Act 2013 konstrukcji „charges”, we współczesnej doktrynie te unormowania były omawiane jedynie w kontekście przepisów koniecznego zastosowania, F. Bauer: Forderungsabtretung..., s. 208.

${ }^{122}$ W. Klyta: Uznanie...,s. 150.

${ }^{123}$ C. Heinze, C.J. Warmuth: The law applicable..., s. 821.

${ }^{124}$ W. Klyta: Uznanie..., s. 150.

${ }^{125}$ Zobacz tezy 19-32 orzeczenia TSUE w sprawie SCI Senior Home v. Gemeinde Wedemark Hannoversche Volksbank eG. 
Lista zarzutów wysuwanych przeciwko rozwiązaniu przyjętemu przez prawodawcę wspólnotowego jest obszerna. Wskazuje się, iż prowadzi ono do uprzywilejowania wierzycieli, którym przysługuje zabezpieczenie $\mathrm{w}$ przypadku otwarcia transgranicznego postępowania. $\mathrm{Na}$ mocy art. 8 r.m.p.u. 2015/848 zostaja im przyznane takie uprawnienia, których z reguły nie mają wierzyciele uczestniczący $\mathrm{w}$ otwartym w kraju w postępowaniu krajowym. Nie uwzględnia ono także tego, iż celem przepisów prawa upadłościowego jest zagwarantowanie równowagi pomiędzy uprawnieniami uprzywilejowanych wierzycieli a interesami masy upadłości. Wątpliwe jest także, czy odpowiada ono potrzebom praktyki. Wreszcie ogranicza także szanse na restrukturyzację majątku dłużnika ${ }^{126}$. Z uwagi na to, iż wierzytelność nie ma swego położenia naturalnego (situs naturalis) niezbędne jest sformułowanie wskazówki odnośnie do jej położenia - przynajmniej na potrzeby międzynarodowego prawa upadłościowego. Wspomnieć należy, iż obszerny katalog definicji znalazł się w art. 2 r.m.p.u. 2015/848. Natomiast art. 2 pkt 9 r.m.p.u. 2015/848 określa pojęcie „państwa członkowskiego, w którym znajduje się przedmiot majątkowy". W tym pomocniczym przepisie przewidziano osiem szczegółowych definicji „miejsca położenia” określonych praw i rzeczy. Wyliczenie to zamyka norma art. 2 pkt 9 ppkt. „viii” r.m.p.u. 2015/848. W myśl tego przepisu: „państwem, w którym znajduje się przedmiot majątkowy - w przypadku roszczeń przeciwko osobie trzeciej innych niż roszczenia dotyczące środków pieniężnych zgromadzonych na rachunkach w instytucji kredytowej — jest państwo członkowskie, na którego terytorium osoba trzecia zobowiąana do ich zaspokojenia ma główny ośrodek swojej podstawowej działalności w rozumieniu art. 3 ust. 1 r.m.p.u. 2015/848”. W konsekwencji wierzyciel, któremu przysługuje zastaw na wierzytelności, cesjonariusz, który nabył wierzytelność „na zabezpieczenie” oraz użytkownik wierzytelności tylko wówczas może zrealizować przysługujące mu zabezpieczenie, gdy dłużnik wierzytelności stanowiącej przedmiot przelewu ma swój główny ośr. podst. dział. na obszarze innego państwa niż to, w którym doszło do ogłoszenia upadłości. Na marginesie zauważyć należy, iż krytykowany przez autorów podejmujacych zagadnienie rzeczowych skutków przelewu łącznik siedziby dłużnika ${ }^{127}$ zyskał aprobatę wśród przedstawicieli międzynarodowego prawa upadłościowego ${ }^{128}$. Jednakże podkreślić należy, iż przypadkowość

${ }^{126}$ P.M. Veder: Cross - Border Insolvency Proceedings and Security Rights A Comparison of Dutch Law, The EC Insolvency Regulation and the UNCITRAL Model Law on Cross - Border Insolvency. Deventer 2004, s. 342.

${ }^{127}$ E.M. Kieninger: Forderungsabtretungsstatut..., s. 701-704.

${ }^{128}$ R. Snowden, w: R. Bork, K. van Zwieten (Edit.), Commentary..., s. 246248. 
rozstrzygnięć wiążąca się z przyjęciem tego kryterium doznaje ograniczenia poprzez przyjęcie przez prawodawcę unijnego subokreślnika temporalnego w postaci chwili ogłoszenia upadłości. Z drugiej strony tak określone miejsce położenie wierzytelności z reguły nie będzie „zgodne” z prawem państwa, któremu ona podlega. Doprowadzi do dalszego skomplikowania procesu zastosowania prawa właściwego ${ }^{129}$.

Konsekwencja zastosowania tego przepisu jest swoiste „zmniejszenie” zasięgu masy upadłości stanowiącej przedmiot zaspokojenia dla tych wierzycieli cedenta, którym nie przysługuja zabezpieczenia rzeczowe. Jedyną możliwością zapobieżenia takiej sytuacji jest wszczęcie $\mathrm{w}$ państwie położenia składników majątkowych obciążonych zabezpieczeniami rzeczowymi wtórnego postępowania upadłościowego. Jednakże jest to uzależnione - w myśl art. 3 ust. 2 r.m.p.u. 2015/848 - od wymogu posiadania przez upadłego cedenta zdefiniowanego w art. 2 pkt 10 r.m.p.u. 2015/848 oddziału ${ }^{130}$.

\section{Prawo, któremu podlega zaskarżenie czynności polegającej na ustanowieniu zabezpieczenia rzeczowego obciążającego wierzytelność w świetle postanowień art. 7 ust. 2 lit. „m" i art. 16 r.m.p.u.}

Fiasko, z którym spotkały się próby wprowadzenia jednolitej regulacji zaskarżenia czynności dokonanych z pokrzywdzeniem wierzycieli ${ }^{131}$, zmusiło tworców r.m.p.u. 1346/2000 do stworzenia propozycji uregulowań kolizyjnoprawnych. Ostatecznie zdecydowano się na regulację składająca się z dwóch części, a zakładajacca swoistą kombinację legis fori concursus i legis causae. Powyższa idea została przejęta w całości do r.m.p.u. 2015/848 ${ }^{132}$. Norma kolizyjna, za pośrednictwem której odszukiwane jest prawo właściwe dla zaskarżenia czynności dokonanych z pokrzywdzeniem wierzycieli, złożona jest z dwóch przepisów. Chodzi tu $o$ art. 7 ust. 2 lit. „m” i art. 16 r.m.p.u. 2015/848. Według art. 7 ust. 2 lit. „m” tego aktu, to statut upadłościowy określa, które czynności

${ }^{129}$ F. Bauer: Forderungsabtretung..., s. 282-283.

${ }^{130}$ T. Hartley: Choice of law regarding..., s. 48.

${ }^{131}$ Zauważyć należy, iż jedną z przyczyn fiaska tego projektu było rozszerzenie Wspólnoty o nowe państwa członkowskie.

${ }^{132}$ C. Thole: Die Einrede des Anfechtungsgegners..., s. 388-392. 
dokonane przez dłużnika przed otwarciem postępowania są nieważne, zaskarżalne lub bezskuteczne. Natomiast w art. 16 r.m.p.u. 2015/848 znalazł się interesująco sformułowany wyjątek od zastosowania tego statutu, określony nieprecyzyjnie przez F. Garcimartína i M. Virgósa jako „bezpieczna przystań" (safe harbour) ${ }^{133}$. Ten ostatni przepis pozwala osobie, która odniosła korzyść z czynności dokonanej przez dłużnika z pokrzywdzeniem wierzycieli, na wykazanie, iż czynność podlega innemu prawu niż statut upadłościowy i zgodnie z tym prawem nie podlega ona zaskarżeniu.

Ta regulacja odnosi się również w myśl art. 8 ust. 4 r.m.p.u. 2015/848 do czynności ustanawiajacej prawo rzeczowe w rozumienie europejskiego międz. pr. upadł134.

Pojęcie „czynność prawna” zastosowane w zakresie tej normy oznacza wszystkie działania wywołujące skutki prawne, dokonane zarówno w sferze prawa materialnego, jak i procesowego, nie wykluczając czynności podjętych w toku postępowania egzekucyjnego ${ }^{135}$. Jednakże zakres normy określonej w art. 7 ust. 2 lit. „m” r.m.p.u. 2015/848 nie jest ograniczony jedynie do czynności prawnych, które w myśl legis fori concursus podlegają zaskarżeniu, lecz obejmuje on także te działania, które według statutu upadłościowego sa nieważne lub wzruszalne z tego powodu, że prowadzą do pokrzywdzenia wierzycieli. Przesłanki, od których zależy jej zaskarżenie, należy oceniać na mocy przepisów państwa, w którym otwarto postępowanie upadłościowe. Statut upadłościowy obejmuje swym zakresem również przesłanki dochodzenia unieważnienia lub ubezskutecznienia danej czynności przed sądem. Według tego systemu prawnego, należy oceniać rodzaj wadliwości, którą obciążona jest czynność prawna. Statut upadłościowy rozstrzyga również o tym, czy orzeczenie sądu wywołuje skutki wsteczne. Prawu państwa otwarcia postępowania podlegają też zagadnienia związane z legitymacją procesową do wniesienia powództwa. W postanowieniach prawa państwa otwarcia postępowaia upadłościowego należy również poszukiwać terminów dochodzenia roszczeń, jak również zakresu obowiązku zwrotu przedmiotów bezprawnie oddzielonych od masy ${ }^{136}$.

Według art. 7 ust. 2 lit. „m” r.m.p.u. 2015/848 do zaskarżenia uprawniony jest nie tylko zagraniczny zarządca, lecz także poszczególni wie-

${ }^{133}$ F. Garcimartín, M. Virgós, w: R. Bork, K. van Zwieten (Edit.), Commentary..., s. 289.

${ }^{134}$ F. Garcimartín, M. Virgós, w: R. Bork, K. van Zwieten (Edit.), Commentary..., s. 287.

${ }^{135} \mathrm{~W}$ tym kierunku — jak się wydaje - podążają również przedstawiciele doktryny niemieckiej, C. Thole: Die Einrede des Anfechtungsgegners..., s. 388-392.

${ }^{136}$ W. Klyta: Uznanie..., s. 174-177. 
rzyciele. Regulacja taka uwzględnia to, iż w niektórych systemach prawnych powództwo może być wytoczone również przez wierzyciela. Nowym, oryginalnym rozwiązaniem jest to, iż kontrahent dłużnika, który odniósł korzyść z czynności prawnej dokonanej z pokrzywdzeniem wierzycieli tylko wtedy podlega ochronie, gdy podczas wytoczonego przez wierzyciela lub zarządce procesu udowodni, że prawem właściwym dla tej czynności jest prawo innego państwa niż państwo, w którym otwarto postępowanie, i zgodnie z tym systemem prawnym czynność nie jest zaskarżalna.

Regulacja ta spotkała się ze zróżnicowaną oceną w doktrynie. I tak: jedni uważaja, że ułatwi ona zarząd transgraniczna masa upadłości. Inni zgłaszaja przeciwko temu ujęciu zastrzeżenia, twierdzac, że przewidziane w art. 16 r.m.p.u. 2015/848 odwrócenie ciężaru dowodu jest, co najwyżej, uzasadnione co do zaskarżenia czynności w prawie upadłościowym, natomiast nie dotyczy zaskarżalności z innych powodów, np. wad oświadczenia woli. Rozporządzenie dotyczące prawa upadłościowego nie może prowadzić do sprzeczności z zasadami postępowania cywilnego. W konsekwencji: zawarte $\mathrm{w}$ art. 16 tego aktu odwrócenie ciężaru dowodu dotyczy jedynie niezaskarżalności wypływajacej z przepisów prawa upadłościowego ${ }^{137}$. W pewnym uproszczeniu można stwierdzić, iż gdy dana czynność prawna - według statutu upadłościowego - podlega zaskarżeniu, to osoba pozwana może bronić się swoistym zarzutem prawa właściwego dla tej czynności. Przepis art. 16 r.m.p.u. zapobiega nieważności czynności prawnej wynikającej z postanowień lex fori concursus ${ }^{138}$. $\mathrm{W}$ doktrynie podniesiono, że za wskazanym mechanizmem przemawia to, że jest on mało skomplikowany i o wiele bardziej praktyczny niż tradycyjnie formułowane ujęcia kumulatywne, które zakładają w swej istocie równoczesne stosowanie dwóch statutów.

Należy wyrazić wątpliwości, czy w rzeczywistości wskazane rozwiazanie jest proste. Ponadto należy zauważyć, iż przewiduje ono zachętę dla stron czynności prawnej dokonanej z pokrzywdzeniem wierzycieli do wyboru dla tej czynności prawa państwa, niedopuszczającego w danym przypadku jej zaskarżenia ${ }^{139}$. W doktrynie zauważono, iż skoro pojęcie

${ }^{137}$ W. Klyta: Uznanie..., s. $174-177$.

${ }^{138}$ W. Klyta: Uznanie..., s. 176; P.M. Veder: Party Autonomy and Insolvency Law, w: R. Westrik, J. van de Weide. Party Autonomy in International Property Law, Munich 2011, s. 261-276.

${ }^{139}$ Współczesna wypowiedź TSUE z 8.06.2017 r. (C-54/16) w sprawie w sprawie $V i$ nyls Italia $S p A, \mathrm{w}$ upadłości, przeciwko Mediterranea di Navigazione $S p A$ jedynie w części przyczyniła się do rozwiania wątpliwości w tym zakresie, bez wątpienia interesujące sa uwagi, poczynione przez TSUE w tezie nr 54 uzasadnienia do tego orzeczenia; I tak: „stosowanie art. 13 rozporządzenia nr 1346/2000 w sytuacji takiej jak rozpatrywana w postępowaniu głównym można wykluczyć wyłącznie wtedy, gdy obiektywnie wynika, że realizowany przez ów przepis cel, polegający w tym kontekście na zapewnieniu stro- 
siedziby cedenta nawiązuje do kryterium głównego ośrodka podstawowej działalności gospodarczej dłużnika, to prawo właściwe dla oceny rzeczowych skutków przelewu stanowić będzie jednocześnie statut upadłościowy w rozumieniu art. 7 ust. 1 r.m.p.u. $205 / 848^{140}$. Umożliwi to zarządcy ubezskutecznienie czynności, na mocy którego ustanowiono prawo zabezpieczające na wierzytelności, w konsekwencji wierzyciel, któremu przysługuje zabezpieczenie nie może powołać się na zarzut lex causae, gdyż rzeczowe skutki przelewu podlegają prawu otwarcia postępowania upadłościowego. Jednakże bliższej analizy wymaga — określone w art. $16 \mathrm{pkt}$ 1 r.m.p.u. 2015/848 sformułowanie „czynność ta podlega prawu innego państwa członkowskiego niż państwa wszczęcia postępowania”. Gdyby przyjąć, iż chodzi tu o rzeczowe skutki przelewu, to zarządca masy upadłości mógłby nadal występować z roszczeniem pauliańskim — zakorzenionym w prawie upadłościowym — bez obawy, że posiadający zabezpieczenie wierzyciel powoła się na zarzut, że w myśl prawa właściwego, nie istnieją możliwości zaskarżenia danej czynności. Dodać należy, iż wypowiedź TSUE z 8.06.2017 r. (C-54/16) w sprawie Vinyls Italia SpA, w upadłości, przeciwko Mediterranea di Navigazione $S p A$ wskazuje na to, iż konstrukcja „obejścia” (fraus legis) w prawie unijnym znajduje się in statu nascendii.

W prawie prywatnym międzynarodowym przyjmuje się zasadę, iż przedmioty czynności rozporządzających „określaja” prawo właściwe. W konsekwencji wierzytelność jako prawo jest związana najściślej z systemem prawnym, któremu podlega. Statut wierzytelności odciska swe piętno na sytuacji prawnej cedenta i dłużnika. Statut, któremu podlega wierzytelność jest przewidywalny oraz może być z łatwością ustalony, co sprzyja pewności prawa. Zawodzi on w przypadku przelewu przyszłych wierzytelności. Wreszcie, w przypadku gdy strony nie dokonały wyboru prawa właściwego, moga powstać trudności w ustaleniu tego, jakiemu prawu podlega wierzytelności. Wskazać należy, iż chociażby na przypadki, w których znajdzie zastosowanie klauzula korekcyjna określona w art. 4 ust. 4 rozp. Rzym I ${ }^{141}$.

nom uzasadnionych oczekiwań co do możliwości stosowania danego prawa, nie został osiągnięty, i gdy umowa została sztucznie poddana prawu danego państwa członkowskiego, czyli zasadniczo w celu niepoddawania faktycznie tej umowy prawu wybranego państwa członkowskiego, lecz powołania się na prawo tego państwa członkowskiego, aby wyłaczyć umowę lub akty wydane w jej wykonaniu z zakresu stosowania lex fori concursus"; stanowić będą przedmiot dalszej debaty naukowej, natomiast w aspekcie praktycznym stwarza ona zachętę dla stron do dokonywania manipulacji prawem właściwym dla określonej czynności prawnej, C. Thole: Die Einrede..., s. 392.

${ }^{140}$ C. Heinze, C.J. Warmuth: The law applicable..., s. 820.

${ }^{141}$ F. Bauer: Forderungsabtretung..., s. 270. 
Współcześnie C. Walsh przypomniała argument, iż zastosowanie prawa, któremu podlega wierzytelnośćc ${ }^{142}$ nie chroni wierzycieli cedenta w wystarczajacy sposób ${ }^{143}$. Znajdują się oni poza „trójstronnym” stosunkiem pomiędzy dłużnikiem, cedentem i cesjonariuszem. Z reguły nie dysponują oni wiedzą o przesłankach, od których uzależniona jest skuteczność przelewu, lub przywilejach na korzyść określonych wierzycieli ${ }^{144}$. W konsekwencji statut wierzytelności pozostawia ich interesy bez ochrony. Przy wyznaczaniu tego statutu uwzględnia się jedynie okoliczność ważnego powstania wierzytelności oraz jej treść, w konsekwencji rozwiazanie to ogranicza kolizyjnoprawną autonomię woli. Próbując przenieść powyższe słabości na płaszczyznę międzynarodowego pr. upadł., można stwierdzić, iż zastosowanie prawa, któremu podlega wierzytelność stanowiąca przedmiot przelewu, doprowadzi do sytuacji, w której wierzyciel posiadający zabezpieczenie rzeczowe może się powołać na art. 16 r.m.p.u. 2015/848 i przeciwstawić roszczeniu zarządcy zmierzającym do ubezskutecznienia czynności dokonanej z naruszeniem zasady par condicio oomnium creditorum zarzutu, iż czynność prawna podlega innemu prawu niż system prawny, w którym otwarto postępowanie, oraz że w myśl tego prawa jest ona w pełni skuteczna. W konsekwencji w skrajnych przypadkach może doprowadzić do zmniejszenia szans na zaspokojenie wierzycieli cedenta.

\section{Podsumowanie}

Dobrym podsumowaniem niniejszych szkicowych rozważań ukazujących wiele aspektów efemeryczności „logiki prawniczej” jest myśl wyrażona przed laty przez Z. Reicha. Autor ten zauważył - in statu nascendii starań unifikacyjnych na płaszczyźnie prawa prywatnego międzynarodowego —, że „to, co jest niemożliwe dziś, może być możliwe

${ }^{142}$ Do łącznika tego nawiązuje doktryna i judykatywa niemiecka, francuska, włoska, jak również postanowienie art. 17 hiszpańskiej ustawy (dekretu królewskiego) z 11 marca 2005 r. zob. Y. Nishitani: Cross - border..., s. 837, przyp. 75 i 76; Także polski prawodawca nawiazzał do tego nurtu w postanowieniu art. 36 ustawy o prawie pryw. międz. z 2011 r. zob. bliżej: W. Kurowski, w: System Prawa Prywatnego, Tom 20 B, Prawo prywatne międzynarodowe, red. M. Pazdan, s. 392-393, Warszawa 2015; tenże, w: Prawo Międzynarodowe Komentarz, M. Pazdan (Redaktor), Warszawa 2018, s. $346-349$.

${ }^{143}$ C. Walsh: The Role of Party Autonomy..., s. 194.

${ }^{144}$ C. Walsh: The Role of Party Autonomy..., s. 194. 
jutro, albowiem w życiu ludzkości pewne idee torują sobie drogę często w sposób niewidzialny i pewnym momencie okazuja się owocami dojrzałymi do zerwania. [...] Wiara w bardzo powolną ewolucję stanowi maksimum optymizmu”145. Jednakże owoce tej „ewolucji” stanowią zazwyczaj wynik kompromisu, który nie uwzględnia oczekiwań uczestników obrotu, aby normy prawne były w jak najmniejszym stopniu skomplikowane. Każde z wchodzących w grę ujęć ma swe wady i zalety. Zyskujący coraz szersza popularność łącznik głównego ośrodka podstawowej działalności cedenta (jego siedziby, zwykłego pobytu) przesuwa punkt ciężkości w stronę - będacych ciągle na początkowym etapie rozwoju - unormowań międzynarodowego prawa upadłościowego. Wiąże się to z niebezpieczeństwem powstania licznych trudności kwalifikacyjnych. Natomiast kryterium prawa państwa, któremu podlega wierzytelność stanowiaca przedmiot przelewu jest idealne dla sądu orzekającego ex post. Jednakże jedynie w ograniczonym stopniu chroni wierzycieli cedenta. Projektowane przez organy Unii unormowanie wskazujące prawo właściwe dla skutków przelewu względem osób trzecich - może jedynie w bardzo ograniczonym zakresie zredukować - podkreśloną przez TSUE w orzeczeniu z 9 października 2019 r. (C-548/18) w sprawie BGL BNP Paribas SA/ TeamBank AG Nürnberg - niepewność prawa ${ }^{146}$. Wskazane wysiłki na płaszczyźnie kodyfikacyjnej stanowią bez wątpienia kolejne potwierdzenie tego, że w wielu specjalistycznych fragmentach prawa prywatnego międzynarodowego państwowe organy prawodawcze odgrywają jedynie rolę peryferyjną ${ }^{147}$.

${ }_{145}$ Z. Reich: Recenzja pracy La codification du droit international privé (Opinions de M.M. Arminjou, Caloyanni, Cassin, Govare, Grunebaum, Le Fur, Lepaulle, Lévy-Ullmann, Niboyet, Ripert), Paris, Libraire génerale de droit 1932, s. 98, ” Przegląd Prawa i Administracji” Rok LIX 1934, s. 155-157.

${ }^{146}$ Interesujaca metaforę skonstruował współcześnie M.F. Müller. Autor ten przyrównał uczestników debaty naukowej podejmujacych zagadnienia rzeczowych skutków przelewu do pozbawionych wszelkich złudzeń bohaterów - pochodzącego z 1952 r. „antydramatu” autorstwa S. Becketta, zatytułowanego Czekajac na Godota, tenże: Drittwirkungen..., s. 523.

${ }^{147}$ D.P. Fernández Arroyo: Denationalising Private International Law..., s. 45. 